\title{
A Tale of Two Churches Court and Parish Projects at St. Stephen's in Vienna
}

\author{
Tim JUCKES
}

\begin{abstract}
The article explores St. Stephen's in Vienna as an ensemble of visual media that responded to the devotional and commemorative needs of its late medieval congregants. A holistic approach to aspects of the church's architecture and integral sculpture is used to refine the prevailing view of the church as an emblem of Habsburg patronage. On the basis of the wide-ranging plan changes that were adopted in the period after Rudolf IV's death, it is argued that the parish's patrician elite came to play a pivotal role in shaping one of Central Europe's most important city churches.
\end{abstract}

Keywords: Vienna, St. Stephen's Cathedral, Middle Ages, architecture, sculpture, visual culture

Late medieval St. Stephen's has often been viewed through the lens of Habsburg patronage. A tendency that was already apparent in early research has proved tenacious: as recently as 2007, Johann Josef Böker's architectural monograph referred to the church as a "symbol of the House of Austria" on its cover, immediately evoking a courtly rather than an urban entity - more Kaiserdom than Stadtpfarrkirche. ${ }^{1}$ The building history has been structured accordingly around rulers - with the so-called Albertinian choir (by c. 1340) generally followed by Rudolfinian projects for the transepts, towers, and nave (1359

\footnotetext{
* I would like to thank the following for help with this article: Barbara Schedl (who generously shared her database of primary sources and the results of her ongoing research), Michaela Schuller-Juckes, Michael Viktor Schwarz, Franz Zehetner, and the clergy and staff of St. Stephen's.

1 BÖKER, J. J.: Der Wiener Stephansdom: Architektur als Simnbild für das Haus Österreich. Salzburg 2007.

2 On the building history with full literature, see Günter Brucher's entry in Geschichte der bildenden Kunst in Österreich Band 2: Gotik. Ed.: BRUCHER, G. Munich 2000, pp. 281-
}

onwards), before Friedrich III is cast as the executor of his ancestors' unfinished plans and driving force behind the elevation to cathedral status in $1469 .^{2}$ Sequencing may have varied, but formative roles in the church's conception have normally been reserved for the court and the masters it recruited.

Agency at St. Stephen's, however, was a composite and shifting phenomenon. While the Habsburgs' de facto rights of patronage over the church acquired legal status during the fourteenth century, the long-running dispute with the diocesan authorities in Passau continued. ${ }^{3}$ Despite important princely

284. See also since then BÖKER, J. J.: Architektur der Gotik. Vienna 2005; BÖKER 2007 (see in note 1); Der Dombau von St. Stephan. Die Originalpläne aus dem Mittelalter, exh. cat. Eds.: KRONBERGER, M. - SCHEDL, B. Vienna 2011; Archäologie und Bauforschung im Wiener Stephansdom. Quellen zur Bangeschichte des Domes bis zum Ende des 13. Jahrbunderts. Ed.: HOFER, N. Vienna 2013; SCHEDL, B.: St. Stephan in Wien. Der Bau der gotischen Kirche (1200-1500). Vienna 2018.

3 FLIEDER, V.: Stephansdom und Wiener Bistumsgründung: Eine diözesan- und rechtsgeschichtliche Untersuchung. Vienna 1968, pp. 58-70; WEIBENSTEINER, J.: Zwischen Bischof und 
interventions in the church's rebuilding, moreover, it was the parishioners - the Vienna burghers, represented by the city council and the "church-master" (Kirchmeister) it appointed - that normally ran the show. ${ }^{4}$ Even if their role did not go unchallenged, the burghers financed and administered much of the work undertaken, particularly after the flurry of ducal activity under Rudolf IV (1358-65). ${ }^{5}$ The sources also make clear that the parts of the complex then under construction - the nave and transepts - formed a spatial entity closely connected to urban society. This lay church was one of several institutions housed under a single roof - sometimes described by contemporaries as the parish church at St. Stephen's and distinguished from the predominantly clerical sector to the east of the choir screen, where Rudolf's foundations and mausoleum were installed (figs. 1-2). ${ }^{6}$

The sense of a heterogeneous site and a project primarily under civic control sits uneasily with the pivotal role assigned to the Habsburgs throughout the period - the notion of grand Rudolfinian plans that were partly realized in the duke's lifetime and then posthumously continued with the burghers' support. In response to this tension, the present essay re-assesses the relationship between patronage and visual media at St. Stephen's in the decades after

Herzog. Die Pfarrer der Pfarre Wien (St. Stephan) von 1282-1365. In: Beiträge zur Wiener Diözesangeschichte, 31,1990, pp. 2-7; WOLFINGER, L.: Die Herrschaftsinszenierung Rudolfs IV. von Österreich: Strategien, Publikum, Rezeption. Cologne 2018, pp. 130-131. The bishop's last challenge to the Habsburgs' rights of patronage over the church came shortly after the death of Rudolf IV.

${ }^{4}$ FLIEDER 1968 (see in note 3), pp. 73-108; PERGER, R.: St. Stephan und die Wiener vom 12. bis zum 19. Jahrhundert. In: 850 Jabre St. Stephan: Symbol und Mitte in Wien 1147-1997, exh. cat. Ed.: KASSAL-MIKULA, R. Vienna 1997, pp. 36-54; SCHEDL 2018 (see in note 2), pp. 75-92.

5 Rudolf IV planned to place the church fabric under the control of his chapter; see Flieder 1968 (see in note 3), p. 92.

"Usage was not uniform, but the term "parish church" often referred to the nave. See, for example, the record of a house sale from 6 December 1367, which mentions two nave altars (of St. Catherine and St. Martin): ... Cbü̈rat zu den zeiten chappellan sant Kathrein alter, gelegen in unser vrowen abseiten enmitten in Sand Stephans pharrchirichen ze Wienne... in sand Merten chappellen gelegen
Rudolf's death. Drawing on several aspects of the church's architecture and integral sculpture, it seeks holistic perspectives on the development of a multifaceted project. With the focus on various forms of plan change, the aim is to establish how far an initial scheme for what has been called a Herzogs- or Eraherzogskirche - an "archducal church"7 - assumed an increasingly civic character, which itself was then obscured by post-medieval interventions.

\section{I. "wann man die machet..." or "when they do it...": The project in written sources, c. 1365-1420}

An indication of the course of post-Rudolfinian work comes from written sources. This begins with circumstantial evidence of an interruption to building in or soon after 1365, when Rudolf's successors were faced with both enormous debts and unfinished projects. ${ }^{8}$ Their immediate response was to place some of his most important institutional plans on ice - including the collegiate chapter at St. Stephen's: the resources that Rudolf had allocated were retracted and only replaced, in a reduced form, from 1368 onwards; by this stage, most of the canons had resigned and left St. Stephen's to return to other positions. ${ }^{9}$ At the same time, the very legality of the foundation was

in der vorgenanten pharrchirichen dacz Sand Stephanne ze Wienne...; Quellen zur Geschichte der Stadt Wien I/2 (QGStW). Ed.: Alterthums-Verein zu Wien. Vienna 1895-1927, no. 1673. The chapter's setting was also perceived as a distinct entity - "the church of All Saints' at St. Stephen's": domino Petro tunc temporis capellano altaris Beate Virginis in ecclesia omnium sanctorum ad Sanctum Stephanum..." (in reference to the Marian altar in the north choir; 10. 10. 1384; QGStW III/1, no. 1683) or ze aller heiligen tumchirchen ze sand Stephan (20.11. 1369; QGStWI/4, no. 3516).

7 On the closely related term Herzogenwerkstatt, which was introduced by Franz Kieslinger in 1923, see SCHEDL 2018 (see in note 2), p. 11 (n. 4). The term Erzherzogskirche is used by Marlene Zykan to describe the Rudolfinian project; ZYKAN, M.: Der Stephansdom. Vienna 1981.

8 On the financial problems: VANCSA, M.: Geschichte Niederund Oberösterreichs, Band 2: 1283 bis 1522. Stuttgart 1927, pp. 168-170. For a comprehensive account of Rudolf's projects in the context of his broader rulership strategies, see WOLFINGER 2018 (see in note 3).

9 FLIEDER 1968 (see in note 3), pp. 200-204. 


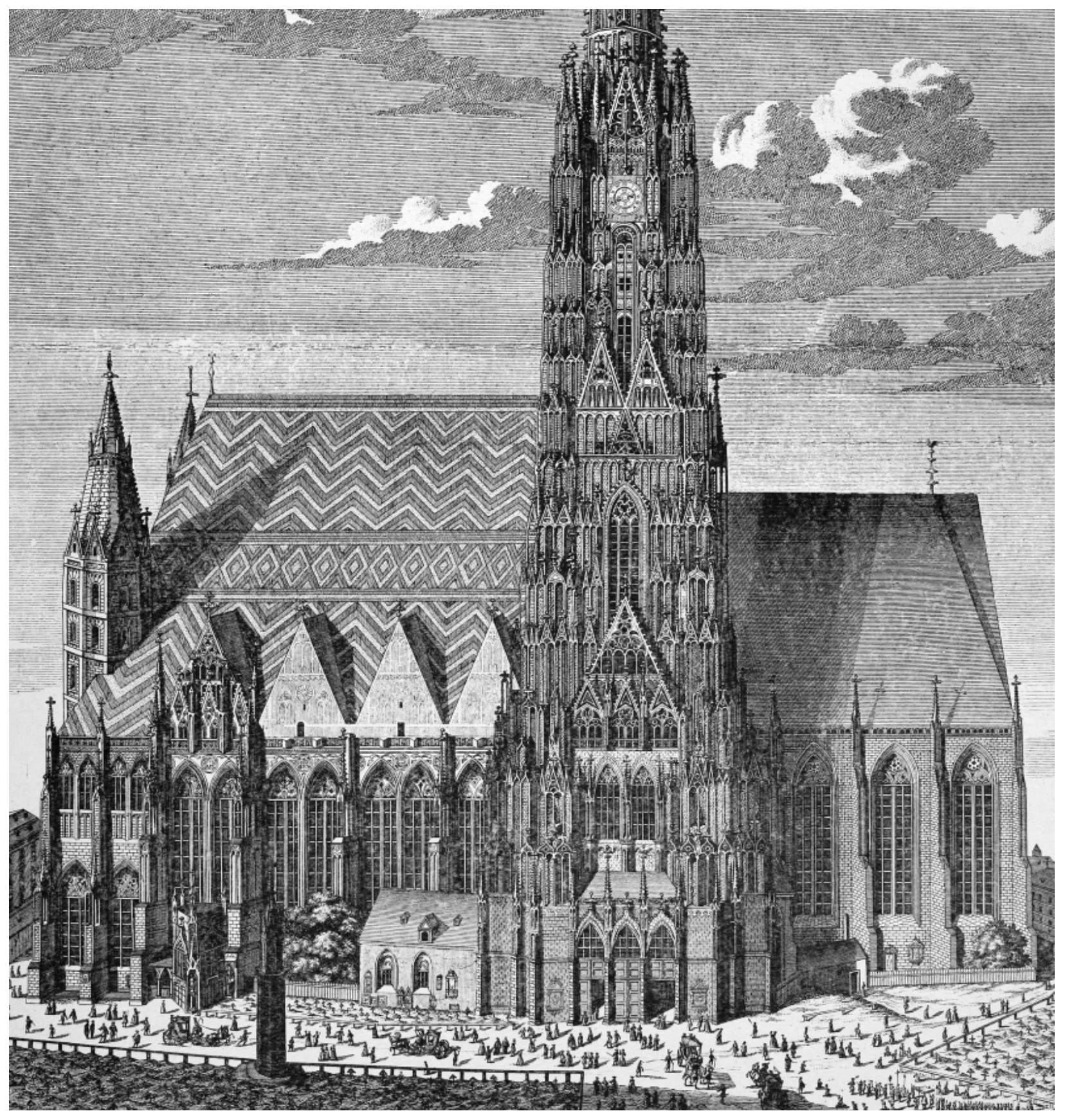

Fig. 1.: St. Stephen's, view of south side, engraving by Salomon Kleiner. Repro: KLEINER, S. - PFEFFEL, J.: Wabrhaffte und genaue Abbildung Aller Kirchen und Klöster, Welche sowobl in der Keyßßerl. Residen₹- Statt Wien, als auch in denen umliegenden Vorstätten sich befinden. Augsburg 1724.

challenged by the Bishop of Passau, who restated his claim to the patronage of the church. ${ }^{10}$ While these crises were ultimately overcome and a lasting basis was created for the chapter's 24 canons, the process took time and the project proved vulnerable without its initiator: key elements of the original foundation

${ }^{10}$ Ibidem, p. 201. 
- such as the additional plan for a body of 26 chaplains - were abandoned; some of the finer details, including the canons' extraordinary privilege to dress in the manner of cardinals, had to be dropped. ${ }^{11} \mathrm{~A}$ similar fate awaited another foundation that was intimately connected with the chapter in terms of personnel and their common seat in the choir at St. Stephen's - the new university, established in 1365: still lacking both basic resources and the necessary papal support for its proposed theological faculty, it emerged as a functioning institution only after the Albertinian re-foundation in $1384 .{ }^{12}$ With Rudolf's various projects thus confronted by a range of existential threats and delays, it is hard to imagine that any extravagant building campaign at St. Stephen's - which ultimately sought to create a worthy setting for the new institutions and the ducal mausoleum could have been sustained.

This unfavourable constellation is accompanied by a lack of direct evidence for building activity before the late 1370 s at the very earliest. ${ }^{13}$ The first hints come from two burgherly testaments of 1377 and 1380, both containing legacies "for the building" (zum Bau) at St. Stephen's - 30 guilders in the first case, 5 guilders in the second. ${ }^{14}$ While the non-speci-

\footnotetext{
${ }^{11}$ Ibidem, pp. 200-201.
}

${ }^{12}$ On the university project with further literature: REXROTH, F.: Planskizze für ein Luftschloss. Die rudolfinische Stiftungsurkunde von 1365 und die Entstehung der Wiener Universität. In: Wien 1365: eine Universität entsteht. Eds.: ROSENBERG, H. - SCHWARZ, M. Vienna 2015, pp. 14-27. On the close connections to the chapter, see WOLFINGER 2018 (see in note 3), pp. 255-260.

${ }^{13}$ Various sources offer insights into the church's finances, but fail to provide evidence of continuing work or a growing concentration of resources on the building project at St. Stephen's. Most notably, a series of civic registers that summarize legal transactions from 1368 onwards (Kaufbücher, Satabücher) shows that the owners of many Viennese properties were obliged to make regular "service payments" (Dienstzablungen) to St. Stephen's. The entries, however, mention only pre-existing stipulations that had been established at an earlier date for unspecified purposes. A comparative view of the material as a whole, moreover, shows that St. Stephen's was neither the only, nor the most important beneficiary of such rights. Numerous payments of the same sort were made to other institutions, particularly the female monasteries, the Teutonic Order, and - the most common recipient of such payments - the civic fic formulation "for the building" could also be connected to ongoing maintenance at the church, the wills find corroboration in two fines (20 guilders each) imposed by the city council almost simultaneously $(1377,1381)$ and with the same beneficiary ("for the building" of St. Stephen's). ${ }^{15}$ A series of wills from before 1377, in contrast, includes no such provisions for the church. ${ }^{16}$ As will be shown below, this apparent convergence of municipal and private efforts to raise money for the fabric in the late 1370s corresponds with aspects of the architectural evidence, which imply that a new campaign of work must at least have been in planning by this time.

The first direct reference to the ongoing project comes as late as 1390, when a burgher left money for work on the side-aisles of the nave. ${ }^{17}$ The testament, however, also reveals that the building campaign was only anticipated: planning posthumous measures while declaredly in good health, the testator specified that the funds for the side-aisles should only be apportioned "when work begins" or, more literally, "when they do it" (wann man die [abseitten] machet). Such a formulation implies that work on the side-aisles was foreseeable, but either had not

hospital (Bürgerspital). For the sources: QGStW III/1 and III/3 (see in note 6). Also SCHEDL 2018 (see in note 2), p. 93.

14 Testament of 5 April 1377: Wiener Stadt- und Landesarchiv (WStaLA), Bürgerspital, Urkunden (1264-1843) 299 (http:/ / monasterium.net/mom/AT-WStLA/HABsp/299/charter). Testament of 25 May 1380: QGStWII/1 (see in note 6), no. 983.

${ }^{15}$ QGStW II/1 (see in note 6), nos. 923 (12 December 1377) and 997 (18 January 1381).

${ }^{16}$ This includes two elaborate wills from the city archive that made provisions for commemorative masses at St. Stephen's, but left no money for the building: see QGStW II/1 (see in note 6): nos. 765 (9 October 1369) and 889 (21 October 1376); see also no. 767 (19 November 1369). Further examples focus on the civic hospital - as did the aforementioned will of 5 April 1377 - but contain no additional provisions for St. Stephen's: WStaLA, Bürgerspital, Urkunden (1264-1843) nos. 239 (6 December 1368), 249 (13 November 1369), 254 (14 December 1370), 266 (1 October 1371), 267 (21 January 1371); all online at monasterium.net.

${ }^{17}$ WStaLA, Bürgerspital, Urkunden (1264-1843) 351 (http:/ / monasterium.net/mom/AT-WStLA/HABsp/351/charter). 


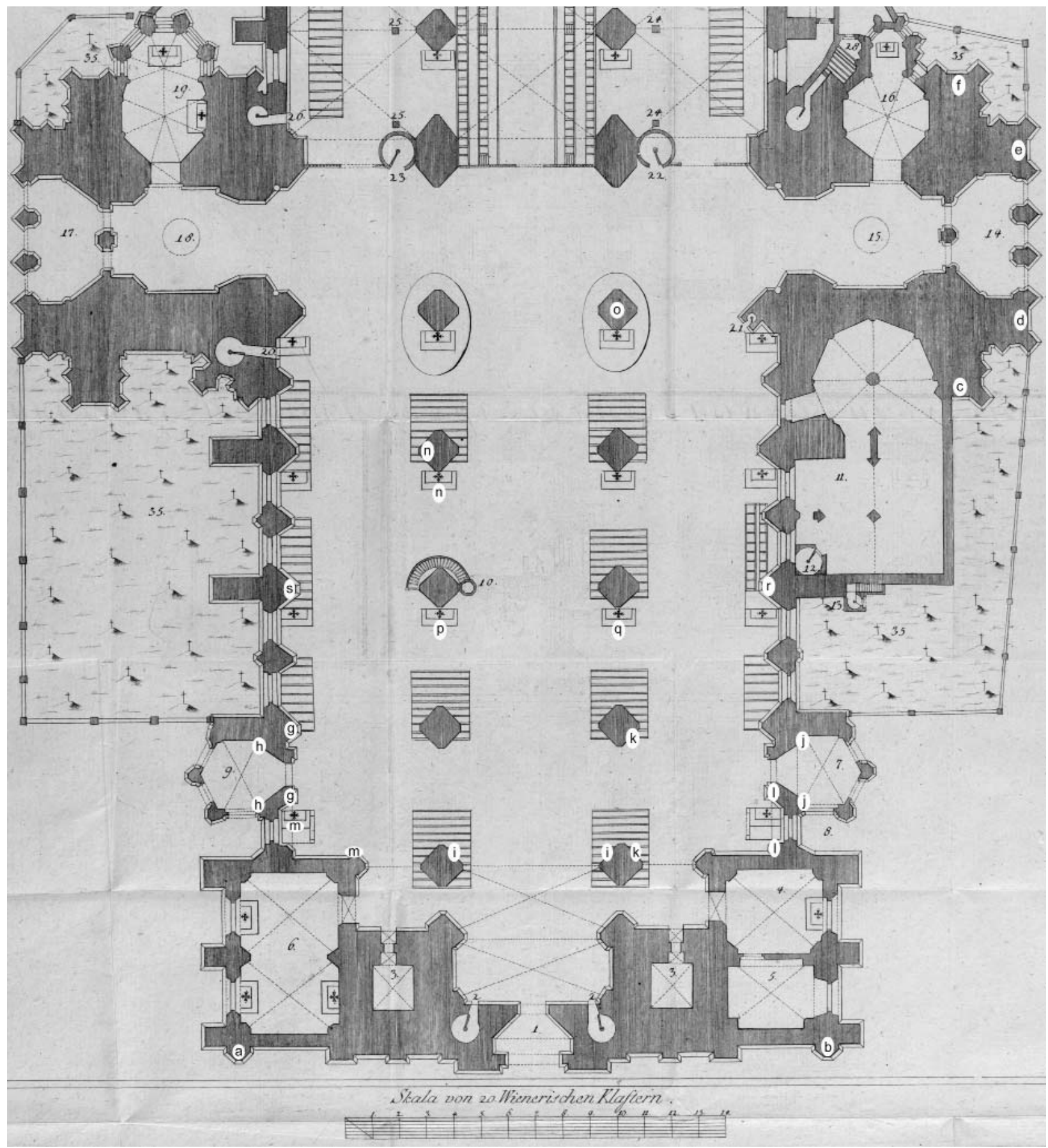

Fig. 2.: St. Stephen's, groundplan showing condition c. 1700-18, engraving published 1791. Repro: GEUSAU 1791 (see in note 38 ).

Original numbering relevant here: 1: West portal (Riesentor); 7: South-west side portal (Singertor); 9: North-west side portal (Bischofstor); 10: Pulpit; 11: Nave sacristy; 16: Chapel of St. Catherine; 22-23: Stairs to imperial oratorium and music gallery; position of former choir screen. Additional lettering: a-f: Fürstenfiguren: a: Katharina; b: Rudolf; c: Blanche; d: Karl; e: Albrecht; f: Johanna; g-s: Pier figures and altars: g: Inner Annunciation of north-west portal; $h$ : Outer Annunciation; $i$ : Annunciation of west gallery; $j$ : Moses and Christ the Saviour; $k:$ Helena and Moses; l: Bishops flanking the altar of St Martin; m: Figure and altar of St. Andrew; n: Group with St. Catherine and her altar; 0 : Epiphany group; p: Altar of All Souls; q: Altar of All Saints; r: Passion group; s: Resurrection group. 
yet started or had been interrupted. ${ }^{18}$ Slightly later sources suggest that a building campaign did soon materialize. There are indications, firstly, of ongoing construction work on the south tower, which was connected to the side-aisles and transepts by shared substance on its north side: the chapel of St. Catherine at the foot of the tower was functional by 1396 , while the completion of work on the lower storey of the tower as a whole followed slightly later - shortly before $1407 ;^{19}$ a reference to the demolition of the transept vaults above the choir screen (1404) confirms that not just the tower, but the whole eastern region of the new building was under construction at this time (fig. 2) ${ }^{20}$ Secondly, from around the same time, work on the nave itself is documented and - as Barbara Schedl has recently shown in new detail saw a progressive completion of one section after another, moving from east to west. ${ }^{21}$

The expanded body of source material in this period provides insights not only into the course of building work, but also into its funding and admin-

\footnotetext{
${ }^{18}$ Other Viennese wills from the period use similar expressions. In an example from 18 January 1396, money was left for a bridge that was constructed soon after (c. 1400-2): zu der pruke vor Stubentor, wenn man die gruntfeste anbebt. Another will of 13 July 1400 contains a variety of related expressions for building projects: wenn si daz anhebent... wenn man daz angevengt... wenn man daran pawen wirt... wenn man den machen wirdet. In two of these four cases, it is known that specific building campaigns followed sooner (Chapel of St. Valentine at St. Peter's, completed by c. 1421) or later (Dominicans, rebuilding of the nave, c. 1458-74). In all three cases where the testator left money only "for the building" (without an additional stipulation), moreover, it is known that building campaigns were already ongoing at that time (Minorite church, Maria am Gestade, Stubenbrücke). With its broad spectrum of terms and building projects, this example thus shows a testator identifying both short- and long-term uses for the resources at his disposal. WStLA, A 285/1-3 (Stadtbücher); Brauneder/ Jaritz ed. 1989, nos. 26, 579.
}

${ }^{19}$ By 1396, the chapel had become the setting for an existing altar of St. Catherine (founded by the former church-master Perchtolt der Geuchramer in 1348), which now also received two new mass foundations. See $Q G S t W \mathrm{I} / 4$ (see in note 6 ), no. 4012, QGStW II/1, nos. 323, 1348, 1350, QGStW III/2, no. 2305. On the subsequent progress of work on the tower in the early fifteenth century, see: ZYKAN, M.: Der Hochturm von St. Stephan in Wien, PhD thesis. Vienna 1967, pp. 44-48; SCHEDL 2018 (see in note 2), p. 98. istration: detailed receipt books are preserved for a number of years (thirteen annual volumes between 1404 and 1430), while a series of city books (Stadtbücher, from 1395 onwards) documents a substantial volume of burgherly legacies "for the building". 22 Private donations of this kind formed the most important source of income for the project in the early fifteenth century, typically representing between a third and a half of the church-master's annual income. ${ }^{23}$ Habsburg contributions, by contrast, were limited to the diversion of certain tax revenues, although the origins of this sum and the conditions attached to it are not entirely clear; in the years that it was paid, it made up around $20 \%$ of income. ${ }^{24}$ While there was also some princely assistance in winning indulgences (1398-9, 1403), Albrecht III saw no need to provide for the church in his final will (1395), which included a significant endowment for the re-established university and building funds for the local churches of the Franciscans, Augustinians, and Maria am Gestade. ${ }^{25}$

20 This comes from the 1404 receipt book of the church-master: von dem gerüst auf dem Letter, da man das gewelib abgetragen hat, umb laden und umb holv, das zü demselben gerust genützt worden ist; Uhlirz ed. 1902, 252.

${ }^{21}$ SCHEDL 2018 (see in note 2), pp. 110-114.

${ }^{22}$ On the receipt books with transcriptions: Rechnungen des Kirchmeisteramtes von St. Stephan zu Wien, 2 vols. Ed.: UHLIRZ, K. Vienna 1901-1902; SCHEDL 2018 (see in note 2), pp. 75-92, 170-206. On the city books with transcriptions: Wiener Stadtbücher 1395-1430: 1. 1395-1400. Eds.: JARITZ, G. - BRAUNEDER, W. Vienna 1989; see also the subsequent volumes.

${ }^{23}$ FLIEDER 1968 (see in note 3), pp. 102-108; SCHEDL 2018 (see in note 2), pp. 81-83, 292-293.

${ }^{24}$ FLIEDER 1968 (see in note 3), pp. 103-106; SCHEDL 2018 (see in note 2 ), p. 81.

25 Three in a series of seven papal indulgences granted to the church between 1395 and 1403 followed a request from Duke Wilhelm: the bulls of 19 January 1398, 2 June 1399, and 25 May 1403; none of the bulls makes any mention of planned or ongoing building projects; see QGStW II/1 (see in note 6), nos. 1379, 1429; QGStWI/4 (see in note 6), 3659; SCHEDL 2018 (see in note 2), pp. 94-97. For the Hollenburg contract of 22 November 1396, which formed the basis for executing Albrecht III's will: QGStW I/4 (see in note 6), no. 4166. 


\section{Patterns of plan change}

The evidence reviewed so far suggests an interruption to building work after Rudolf's death and shows how much of the south tower, transepts, and nave was constructed under the auspices of the burghers in building campaigns that intensified towards the end of the fourteenth century. Now I want to turn to the fabric and furnishings of the church to assess how far these phases of construction pursued existing plans from the 1360 s.

Indications of the dynamics behind late fourteenth-century work come particularly from the south tower and its relations with the body of the church (figs. 1-2). On the one hand, the tower's place as an element within the Rudolfinian project has a documentary basis: several contemporary sources point in this direction, while slightly later evidence refers explicitly to the duke's role as initiator of the tower. ${ }^{26}$ On the other, research into the fabric has found signs of a lively building history: after the seductive notion of the tower as a single, coherent concept had been challenged decisively by Hans Tietze (1931), multiple design phases were first identified and explored systematically by Marlene Zykan (1967). ${ }^{27}$ Johann Josef Böker's more recent examination (2007) has added to this framework, but also uncovered a new phase of work: while Zykan saw elements of a Rudolfinian concept retained throughout a series of plan changes, Böker identified an older core at the base of the tower that-encased within later projects - appears to have anticipated

${ }^{26}$ Review of the evidence in ZYKAN 1967 (see in note 19), pp. 13-25. See also BÖKER 2007 (see in note 1), p. 98; SCHEDL 2018 (see in note 2), pp. 52-54.

${ }^{27}$ TIETZE, H.: Geschichte und Beschreibung des St. Stephansdomes in Wien. Vienna 1931, pp. 11-22; ZYKAN 1967 (see in note 19); ZYKAN, M.: Zur Baugeschichte des Hochturmes von St. Stephan. In: Wiener Jabrbuch für Kunstgeschichte, 23, 1970, pp. 28-65.

${ }^{28}$ BÖKER 2005 (see in note 2), pp. 98-105.

${ }^{29}$ BORK, R.: The Geometry of Creation. Architectural Drawing and the Dynamics of Gothic Design. Farnham 2011, pp. 230-357.

${ }^{30}$ BÖKER 2007 (see in note 1), pp. 44-53, 74-94. According to his analysis, the Rudolfinian remodelling involved gutting a a structure far less ambitious than that ultimately executed. ${ }^{28}$ The predominantly post-Rudolfinian character of the realized design has since found acceptance in Robert Bork's geometrical analysis of the tower and its super-regional contexts (2011), which focussed on the subsequent planning process. ${ }^{29}$

Böker's broader interpretation of the Rudolfinian scheme for this part of the church remains contentious in certain respects, particularly his vision of the duke's dramatic remodelling of the choir. ${ }^{30}$ But his identification of the tower's north-east corner as the remnant of an early phase of work seems compelling (figs. 3-4). ${ }^{31}$ The most revealing element is the staircase turret of the tower's north-eastern buttress, which diverges from the architectural systems devised for both the lateral walls of the choir and the tower in its executed form: on its north and west sides, the turret was built into the choir's corner buttressing and shows an improvised response to adjacent fenestration and the frieze beneath the eaves; on its south side, its plain wall surface received more elaborate forms, but only in the course of secondary additions that conform to later phases of work on the tower. More problematic is Böker's proposition that the turret connects to Rudolfinian work on the choir and was executed, as part of a single campaign, together with the south-west corner of the southern aisle. ${ }^{32}$ The internal corner supports (fig. 3, no. 6) may be closer to the forms of the choir's central aisle than to those of its outer walls - thus linking them to later phases of work - but they are far from identical and, most importantly, they show

choir that had been completed as recently as 1340: the outer walls were left standing and partly rebuilt, while the interior was filled with new arcades and vaults. See Marlene Zykan, review of BÖKER 2007 (see in note 1) in Österreichische Zeitschrift für Kunst und Denkmalpflege, 62, 2008, pp. 717-721; Tim Juckes and Michael Schwarz, review of BÖKER 2007 (see in note 1) in Kunstchronik, 62, 2009, pp. 265-274; NUSSBAUM, N.: Der Chor von St. Stephan in Wien. Fragen zu dessen Hallenkonzept und seiner architektursprachlichen Deutung. In: Wiener Jabrbuch für Kunstgeschichte, 62, 2014, pp. 7-20; SCHURR, M. C.: Stilpluralismus, Stilentwicklung oder Hofstil? Gedanken zu Formphänomenen am Chor der Wiener Stephanskirche. In: Wiener Jahrbuch für Kunstgeschichte, 62, 2014, pp. 21-38.

${ }^{31}$ BÖKER 2007 (see in note 1), pp. 98-105.

${ }^{32}$ Ibidem, pp. 85, 100-102. 


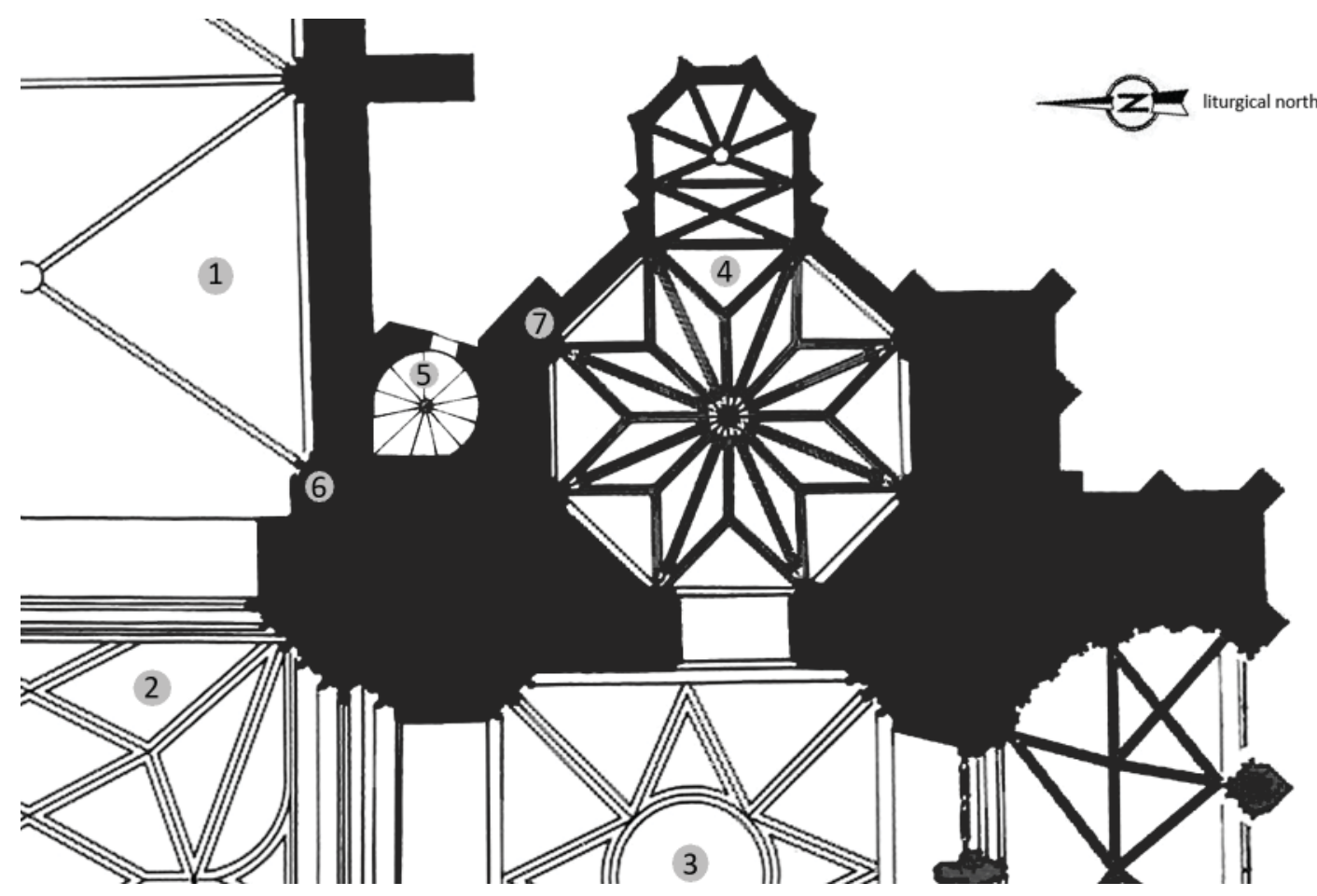

Fig. 3. South tower, groundplan showing eastern half of tower and adjoining structures with: 1: choir; 2: south transept; 3: tower hall; 4: chapel of St. Catherine; 5: staircase turret; 6: south-west corner supports of choir; 7: north-east buttress of tower. Photo: T. Juckes

no structural connection to external elements on the adjoining corner of the tower: the coursing of the masonry does not imply that the supports belonged to the same campaign as the staircase turret, while the interior walls of the stairwell reveal that the turret itself was a secondary structure built into the right-angle of an existing buttress at the choir's south-west corner. ${ }^{33}$

The significance of the staircase turret surely lies in its disassociation from both the choir and the later phases of work on the south tower. It evokes a tower project that was originally conceived as an

\footnotetext{
${ }^{33}$ The forms of the south-west corner are best explained as part of a final phase of work on the choir - i.e. after the completion of the central aisle and north-west corner (which shows a solution that is different to the south-west corner but close to forms found in the apses of the choir). The delayed completion of the south-west corner can be related to the continued presence of predecessor structures in this area, some parts of which may have survived into the late fourteenth century.
}

independent addition to an existing transept, which, at least initially, was to be retained and perhaps remodelled. ${ }^{34}$ Unlike its later northern pendant, the lowest sections of the south tower were not always part of a broader campaign embracing the transepts: masonry breaks between these two components imply separate phases of construction - perhaps even up to the beginning of the double-window stage, $;^{35}$ the retention of old sections of the south-eastern transept wall, which were sandwiched between new structures, confirms that this part of the predecessor church was never comprehensively replaced (fig. 8,

${ }^{34}$ See ZYKAN 1967 (see in note 19), pp. 55, 72-73, 114-115; BUCHINGER, G. - JEITLER, M. - MITCHELL, P. SCHÖN, D.: Die Baugeschichte von St. Stephan bis in das 13. Jahrhundert. Analyse der Forschungsgeschichte und Neuinterpretation unter dem Blickwinkel rezenter Methodik. In: HOFER 2013 (see in note 2), pp. 358-368.

35 BÖKER 2007 (see in note 1), p. 115. 


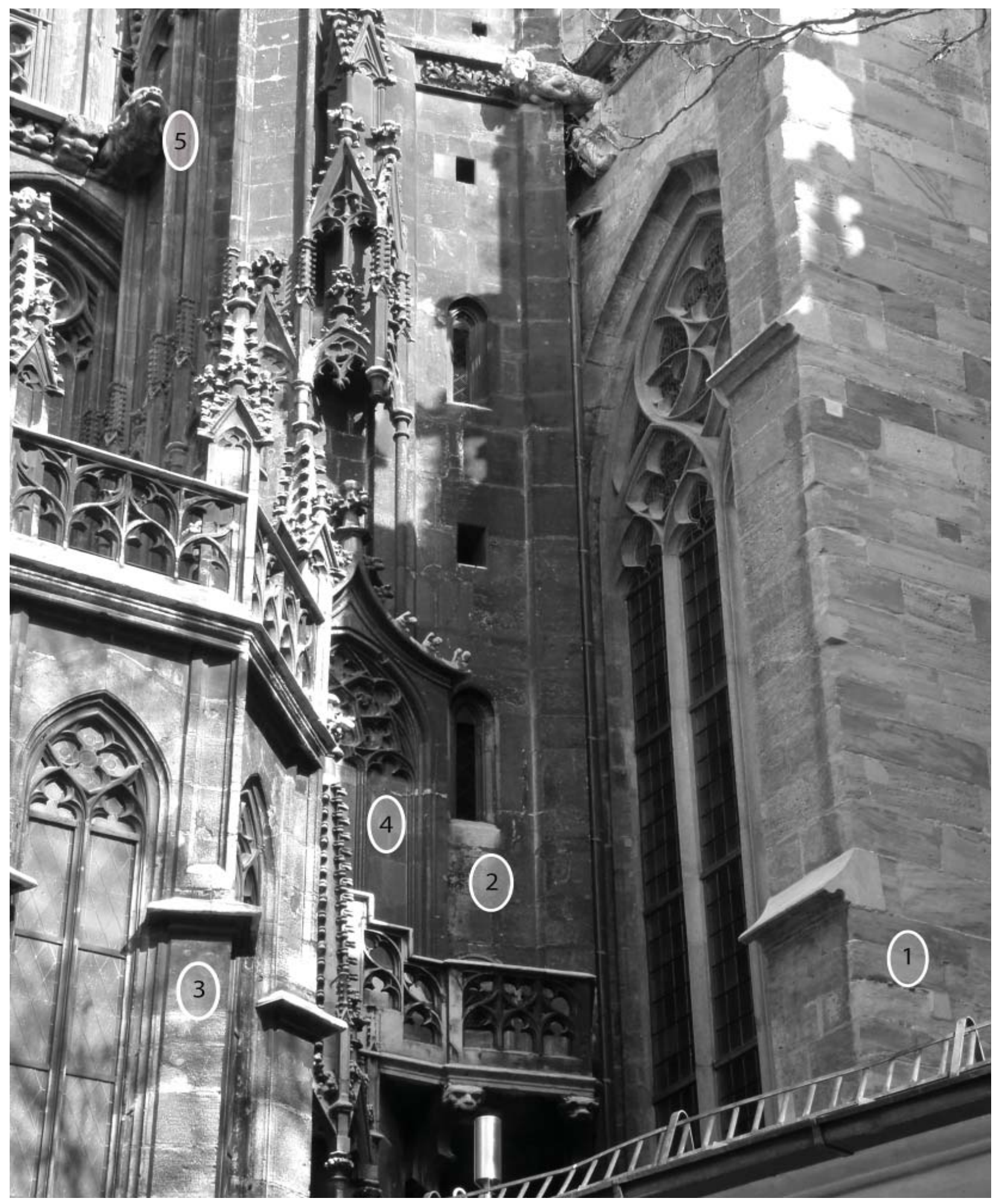

Fig. 4. South tower, north-east corner and junction with choir (looking north-west) showing: 1: choir; 2: staircase turret; 3: chapel of St. Catherine; 4: buttress; 5: gargoyle. Photo: T. Juckes 
no. 1). ${ }^{36}$ It is also striking, finally, that the tower's north-eastern buttressing diverges from the system of its southern corners - and not only in its incorporation of a staircase: it shows a prow-shaped lower stage (fig. 3, no. 7) that was reduced on its south side to incorporate the Catherine chapel, and then - just below the chapel's eaves - cut back abruptly towards the body of the tower. Once again, the north tower - while retaining a staircase in the same position - made corrections and brought this element into harmony with an established buttressing system.

The corresponding position on the opposite side of the south tower - its north-west corner - also shows signs of an earlier scheme that was revised during construction. Following the baroque remodelling of the nave sacristy, which finds its eastern termination between the tower's western buttresses, the original condition is documented only by late medieval drawings and early modern engravings (figs 1-2). ${ }^{37}$ The most important source is a little known but relatively precise groundplan that presents the church's layout in the early eighteenth century: it shows that the sacristy had an eastern sector of octagonal form, which was vaulted on a central support and joined with a quadratic space through improvised openings on its western sides (figs. 2, 5). ${ }^{38}$ Similarly improvised was the slanted connection to

\footnotetext{
${ }^{36}$ See ZYKAN 1967 (see in note 19), pp. 72-73; BUCHINGER - JEITLER - MITCHELL - SCHÖN 2013 (see in note 34), pp. $358-368$.
}

${ }^{37}$ On the remodelling of the sacristy in 1731-32: TIETZE 1931 (see in note 27), pp. 63, 264-270. On the medieval plans: BÖKER 2007 (see in note 1), pp. 189-191.

${ }^{38}$ Published as a large fold-out engraving $(61 \times 44 \mathrm{~cm})$ in the third volume of Anton von Geusau's history of Vienna, the plan is based on a lost original from the first decades of the eighteenth century; see GEUSAU, A.: Geschichte der Hauptund Residen sstadt Wien in Österreich, vol. 3. Vienna 1791, p. 125. Geusau states that the original was the "most precise groundplan" of St. Stephen's and held by the civic authorities, for whom he is known to have worked. The groundplans published earlier by Ignaz Choler (1721), Friedrich Tilmez (1722), and Johann Küchelbecker (1730) appear to have drawn on the same source, but are much smaller $(\mathrm{c} .20 \times 16 \mathrm{~cm})$ and show simplifications. On the basis of the features depicted, the original plan can be dated to after 1700 (refurnishing of the eastern altars of the nave arcade) but before c. 1718 (extension of the choir's northern sacristy, c. 1718-1722); it the nave on the octagon's north-west side, which as the only portal to the space - had to penetrate a massive section of semi-redundant masonry, partly the product of a clash between the octagon and a nave buttress. All this suggests that the space's entrance and orientation were heavily adapted during construction. Indeed, as Böker revealed, the purpose of the fifteenth-century drawings was to work out the detailing of the sacristy's western extension and its difficult relations to the existing octagonal space. ${ }^{39}$ The close correspondence between one of the drawings (Akademie der bildenden Künste Wien, 17.034) and the eighteenth-century plan further confirms the accuracy of both (figs. 5b-5c). While the loss of original substance prevents closer analysis, the measured integration of a complex polygonal body within the tower's buttressing system implies that the octagon was intended from an early stage and conceived as a pendant to the similarly centralized Catherine chapel on the tower's east side. In its apparent disjunction with the present nave, it enhances the impression of an early tower project planned as an addition to existing substance, rather than as part of a systematic rebuilding of the broader complex. In diverging from the support system of the tower's south side, the massive north-western buttress some of which is preserved in the bulky walls of the

can be related to a dynamic phase in the history of Viennese cartography, which included Arnold Steinhausen's detailed survey of the city centre (completed in 1710). Having received little attention, the engraving was recently re-published as a historicizing reconstruction of the church's condition in Friedrich III's time (see PIRKER-AURENHAMMER, V.: Die Passionsreliefs vom Wiener Stephansdom - eine Einführung. In: Die Passionsreliefs vom Wiener Stephansdom. Eds.: HUSSLEIN-ARCO, A. - PIRKER-AURENHAMMER, V. Wien 2009, pp. 15, 18) - an interpretation that is contradicted by the many post-medieval elements. Nor can the plan be regarded as an idealized version of the Tilmez engraving, since it includes a wealth of additional details that can only have been taken from a more precise original or from the building itself. For more on the plan, see JUCKES, T.: An Unnoticed Plan of St. Stephen's in the Early Eighteenth Century and its Implications for the Medieval Building History. In: St. Stephan in Wien. Die Herzogswerkstatt. Ed.: SCHEDL, B. Vienna forthcoming 2021.

${ }^{39}$ BÖKER 2007 (see in note 1), pp. 183-191; see also TIETZE 1931 (see in note 27), pp. 10, 29-31; ZYKAN 1967 (see in note 19), pp. 113-114. 

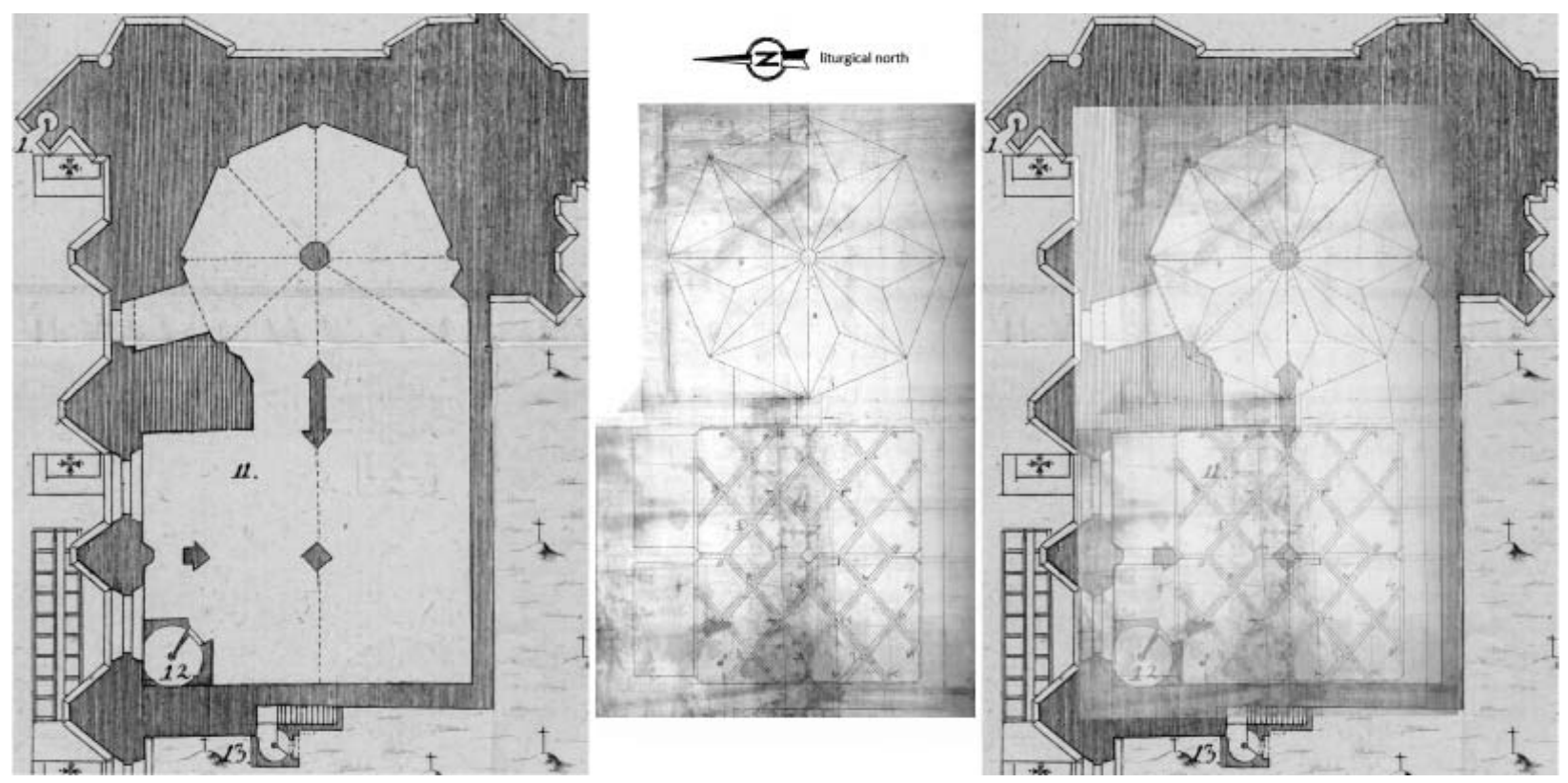

Fig. 5. South tower and nave sacristy: a. Groundplan, showing condition c. 1700-18 (engraving, published 1791; Repro: GEUSAU 1791); b. Groundplan, mid-fifteenth century (ink on paper, $763 \times 485$ mm; Akademie der bildenden Künste Wien, 17.034; Repro: BÖKER 2007); c. Superimposition of fig. 5 b on fig. 5 a

present-day sacristy - recalls the situation observed at the north-east corner.

These remnants of an original concept - established in its foundations and with initial work perhaps prioritizing the northern juncture with the transeptcontrast with both the sequencing and formal choices of subsequent phases. A surviving groundplan of the tower's western half (Akademie der bildenden Künste Wien, 16.819v; fig. 6), which was first identified as such by Marlene Zykan, reveals a series of developments that must have occurred by around $1380 .{ }^{40}$ Despite being a later and imperfect copy, the drawing's detailed passages show a creative focus on the tower's south side - its angle-buttressing and entrance area.

40 ZYKAN 1967 (see in note 19), pp. 120-132; BÖKER 2005 (see in note 2), pp. 68-71; BORK 2011 (see in note 29), pp. 233-242. The dating is based on the documented completion of the Catherine chapel by 1396 and the tower's entire lower stage by 1407 ; it also fits with the documentary evidence from the late 1370s (see above, p. 115-117).

${ }^{41}$ The plan probably always showed only half of the tower. The half-plan format is here implied particularly by the drawing on the other side of the parchment, where a groundplan
Engagement with existing substance and neighbouring structures was not the priority: the north-west buttress appears in outline, but relations to the nave or sacristy are not explored; the entire east side appears to have been omitted and, with it, the specific challenges of the Catherine chapel and the north-east corner avoided. ${ }^{41}$ Engagement with the upper stages of the tower was also limited to the outlines of the second main stage. If the aim was instead to establish a revised substructure for a more ambitious tower, then the drawing can be seen to have achieved this: the form and articulation of the lower buttressing, along with the diagonally-set pinnacle clusters that emerge from it, are close to the executed structure; the porch

of a single-aisle space was executed at around the same time and in clear correspondence to the rectangular form of the parchment $(770 \mathrm{x} 457 \mathrm{~mm})$; the leaf was slightly cut on all sides at a later date; see ZYKAN 1967 (see in note 19), pp. 120-121; BÖKER 2005 (see in note 2), pp. 68-71. Plan drawings with this format and/or a similar focus on the tower core - rather than adjoining structures - can also be found among the more extensive material relating to the north tower (see Akademie der bildenden Künste Wien, 16.820). 


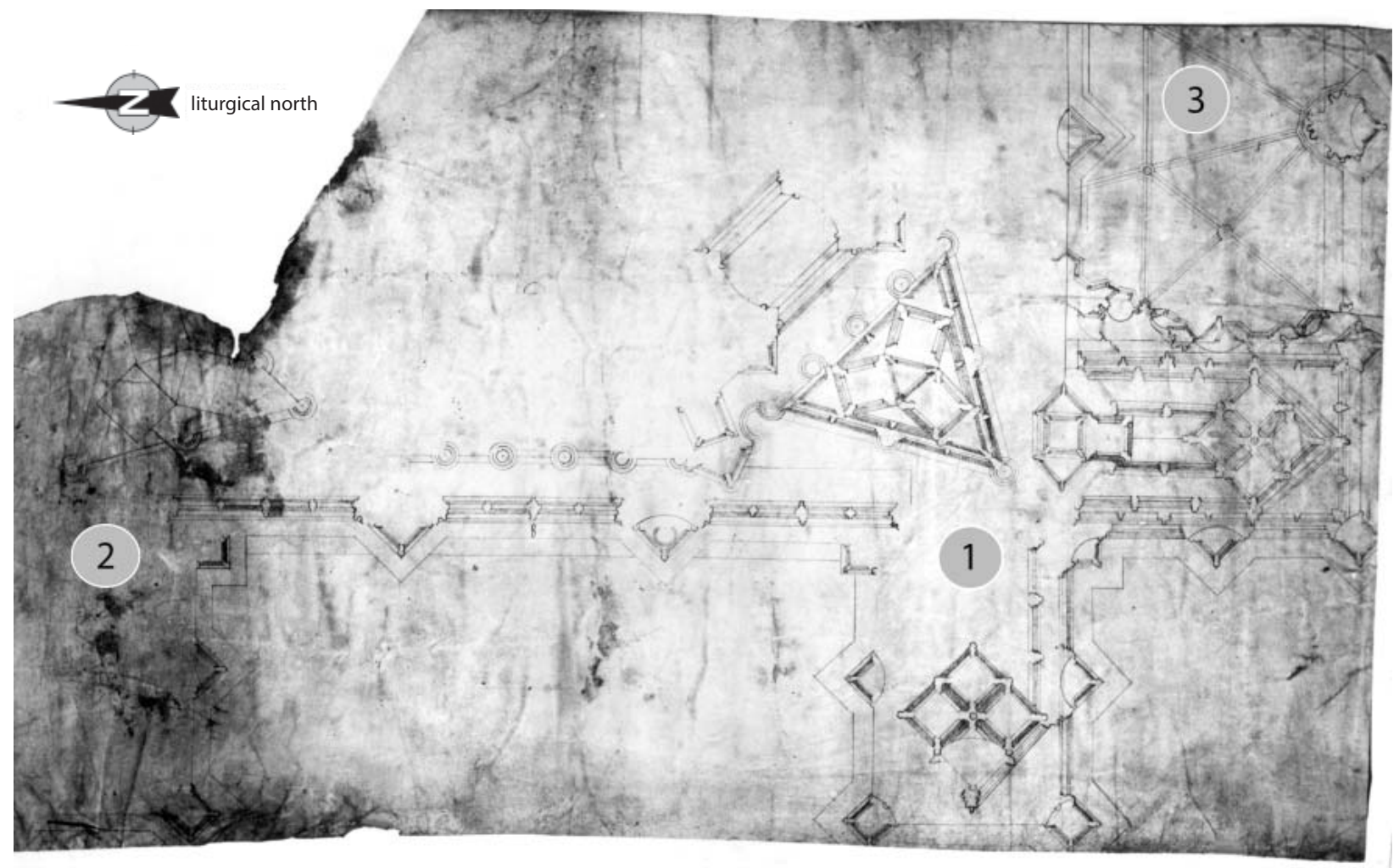

Fig. 6. South tower, groundplan with design c. 1380, (ink on parchment, $456 \times 780$ mm; Akademie der bildenden Künste Wien, 16.819v): 1: south-west angle-buttressing; 2: north-west buttress; 3: porch. Photo: Vienna University, Unidam

area and its detailing, including the delicate handling of the lateral walls and complex vault forms, show only slight deviations; crowning the base stage, finally, is the trademark motif of tripartite tracery gables. ${ }^{42}$ By this height, however, there is growing divergence from the executed tower, and, above the base stage, the differences become dramatic: most importantly, the entire belfry storey of the executed project - a monumental extension of the quadratic base - was omitted from the drawing, where the transition to an octagonal superstructure follows the base stage and deploys a simpler buttressing system that retreats quickly to the structure's core.

\footnotetext{
${ }^{42}$ On the deviations from the executed structure: ZYKAN 1967 (see in note 19), pp. 123-125, 129-32; BÖKER 2005 (see in note 2), pp. 68-71; BORK 2011 (see in note 29), pp. 233-240.

43 This departure involved, on the one hand, major adaptations to the buttressing system in preparation for an enlarged
}

The departure from the drawing's scheme has been convincingly tracked through the upper half of the executed tower's quadratic base - the so-called double-window stage (completed by 1407) - and related to further drawings from the lodge. ${ }^{43}$ Insight into the broader consequences of the plan changes comes particularly from the northern regions of the tower. The north-east corner lays bare the challenges of integrating earlier substance - the staircase turret and its flanking buttress - into the revised plans (fig. 4). Having transitioned from a prow-shaped to an orthogonal front just beneath the eaves of the Catherine chapel, the face of this massive and

superstructure, and, on the other, a marked shift in formal language; both have been convincingly connected to the arrival of Master Wenzel and other personnel from Prague around 1400. See ZYKAN 1967 (see in note 19), pp. 78-109, 120-225; BÖKER 2007 (see in note 1), pp. 105-128; BORK 2011 (see in note 29), pp. 233-254. 

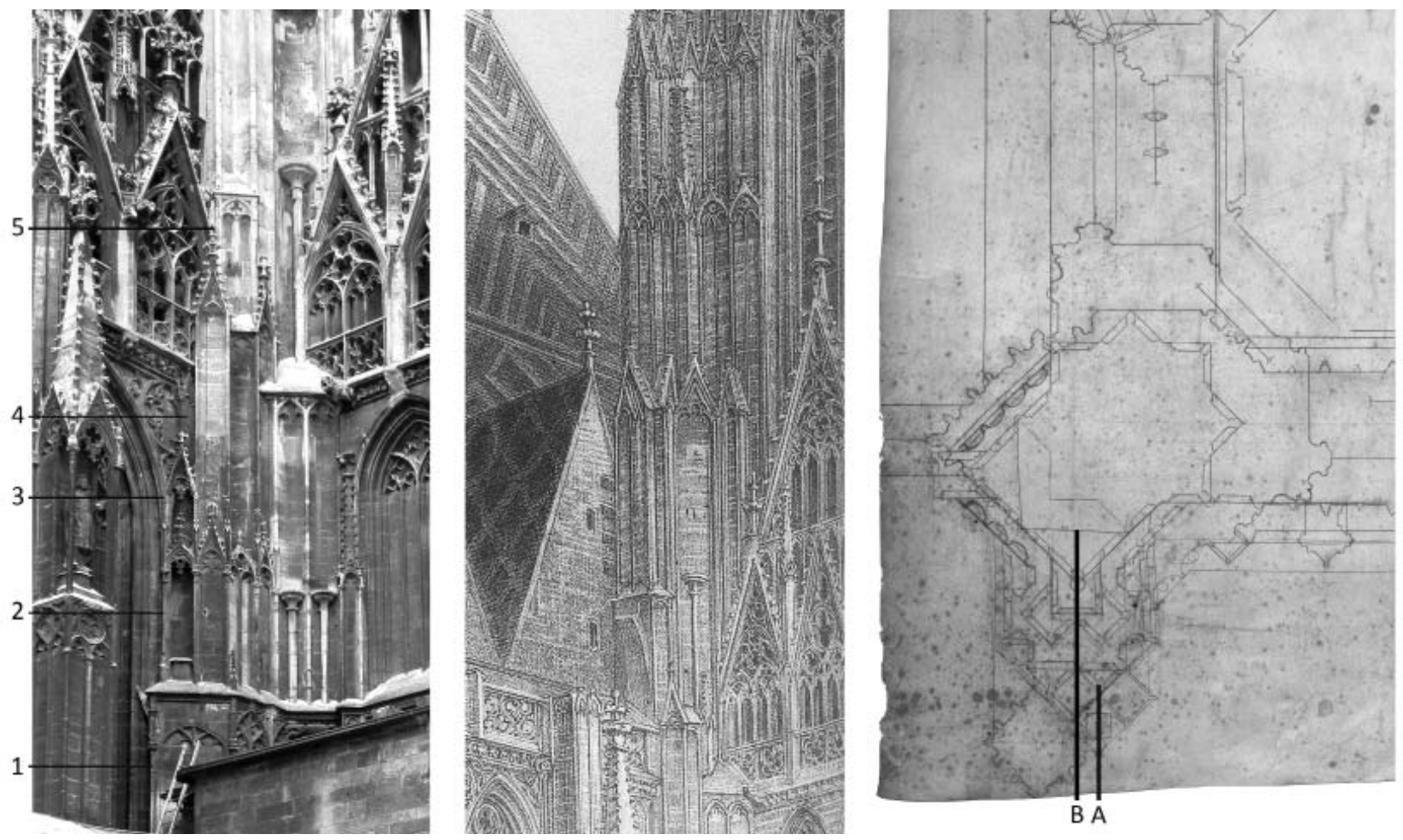

Fig. 7. South tower, north-west junction with nave: a) Photo 2008 (looking north-east) with levels 1-5; b) Engraving by Jakob von Alt, 1852 (showing the nave gable before the addition of its tracery); c) Groundplan from c. 1400, detail with axes A and B (Wien Museum, 105.065). Photos: Vienna University, Unidam

- within the formal world of the south tower singular buttress was treated with blind tracery and then given a broad ogival conclusion (fig. 4, no. 4). Here, at the beginning of the double-window stage, its near-quadratic mass suddenly gives way to more complex recessions that seek conformity with the new buttressing system developed across the tower at this stage. Complete conformity, however, remained elusive and it proved impossible to avoid an untidy collision with the fenestration: the buttress ploughs through the first quarter of the northern window and meets awkwardly with its surround and a displaced gargoyle (fig. 4, no. 5). The severity of this systemic clash is thrown into relief by comparison with the corresponding position on the later north tower, where the integration of a rising staircase

\footnotetext{
44 The north tower's staircase forms part of a monumental buttress that stays close to the forms of the free-standing angle-buttressing on the north side of the tower; the stair-
}

turret within a similar buttress system was planned from the start. ${ }^{44}$

The north-west corner brought an extended range of challenges (figs. 5, 7). On the one hand, there was the bulky substructure of the buttress flanking the octagonal space. On the other, there was the question of integration with the rising structure of the nave, which was also a focus of early fifteenth-century work. The aforementioned medieval groundplan, while not going into any detail, does present the outline of the solution ultimately deployed at the nave junction: a quadratic lower buttress that follows the system of the tower's angle-buttressing and occupies the easternmost half-bay of the nave's south wall (fig. 6, no. 2). As is shown by the forms that emerge from the post-medieval sacristy roof today, this solu-

case turret rises to replace - rather than dissect - one of the openings in the double-window stage. 
Fig. 8. Junction of south-western choir, south tower, and south transept (looking west), following the collapse of the vaults in April 1945, showing: 1: Fragment of frieze from predecessor transept; 2: Base of buttress rising from springing rone; 3: Cantilevering of northern buttress. Photo: Vienna University, Unidam

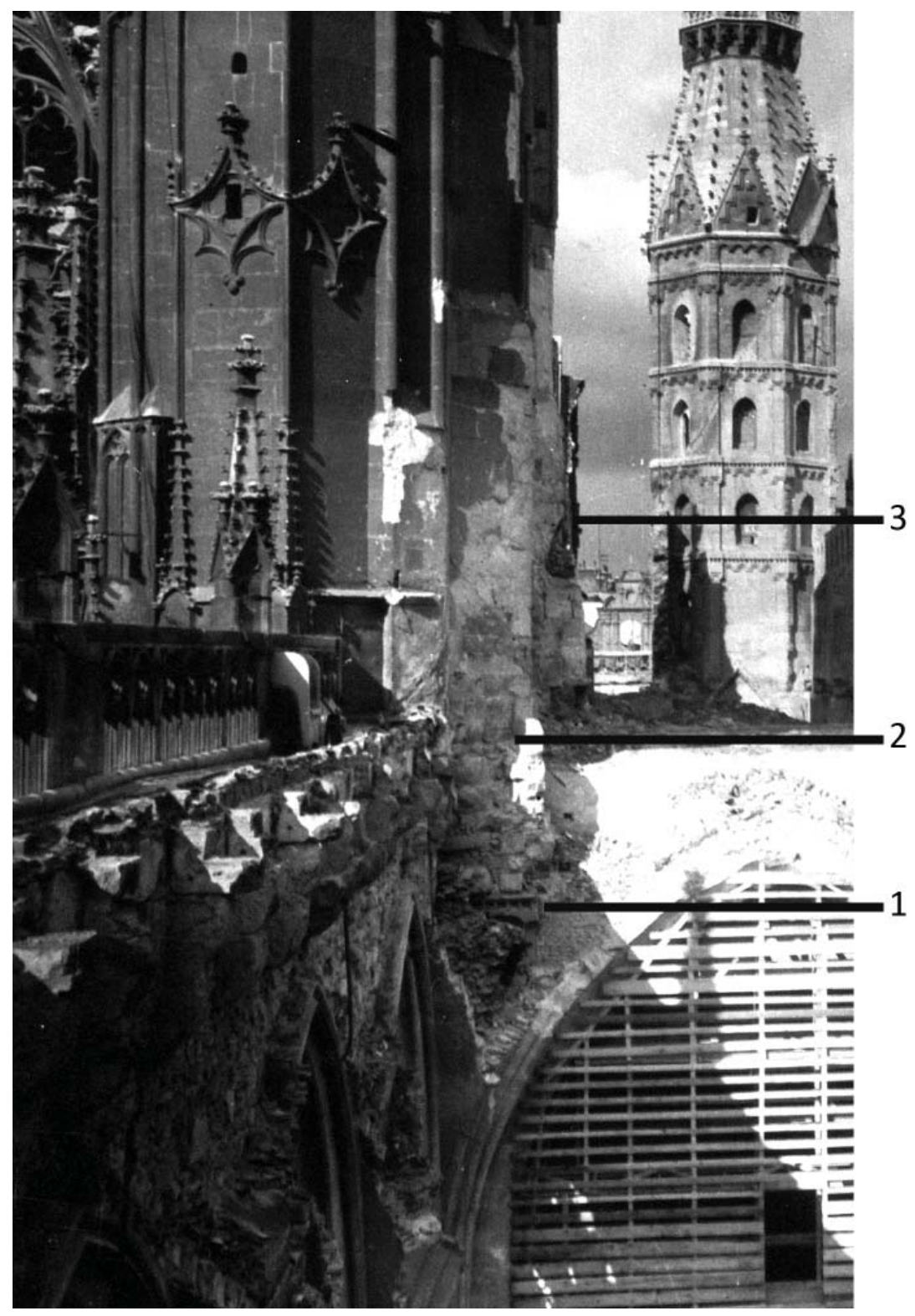

tion had already been adopted in the lower half of the tower's base: the buttress presents a prow-shaped front that was primed to receive a quadratic framework of open tracery in the manner of the southern angle-buttressing (fig. 7a, no. 1). Here and in the buttress's next recession, which produced a diagonally-

\footnotetext{
${ }^{45}$ For detailed analysis of this critical passage of the design, see NUSSBAUM, N.: Beobachtungen zur relativen Chronologie von Langhaus und Südturm des Wiener Stephansdomes. In:
}

-set baldachin, the formal fusion with the nave wall created coordinational difficulties: the window pier shows no anticipation of the arriving tower forms at this point; the connection was initially achieved by improvised attachments of tracery and shaft forms (fig. 7a, no. 2). ${ }^{45}$ Moving further upwards, however,

St. Stephan in Wien. Die Herzogswerkstatt. Ed.: SCHEDL, B. Vienna, forthcoming 2021. 
the coordination becomes more convincing: both the baldachin's finial and the slanted tracery panel above show fusion with the surround rather than purely secondary applications, while the last finial of the fenestration stage achieves close integration with the blind tracery and frieze crowning the nave wall (fig. $7 \mathrm{a}$, nos. 3-4). The subsequent gable stage shows still greater assurance: the tower buttress recedes further to present a west-facing wall surface not found at the other corners - a motif that provides a two-storey docking zone carefully tailored to the formal needs of the arriving gable and sub-gable of the nave's crown (fig. $7 \mathrm{a}$, no. 5 ; fig. $7 \mathrm{~b}$ ).

The degree of adaptation involved in this passage of the design is evident in the accompanying shift of the entire east-west axis of the tower's north side, as is shown in fig. 7c: from the prow-shaped buttress to the finial clustering at frieze level, the forms recede eastwards as they rise in conformity with the south-west corner of the tower (fig. 7c, axis A); at this point, however, they make a northward step that forms the basis for a further series of eastward recessions in the next stage (fig. 7c, axis B). ${ }^{46}$ On one level, this step facilitated fusion with the gables by creating the aforementioned docking zone; on another, it was part of the broader expansion of the tower's superstructure introduced in the double-window stage. As was clearly visible after the fire of 1945, the increased volume of buttressing was partly enabled by various forms of cantilevering on the tower's north side (fig. 8, no. 3). The lack of long-term preparation for this development is most apparent in the massive sections of masonry that

\footnotetext{
${ }^{46}$ See ZYKAN 1967 (see in note 19), pp. 87-91.

${ }^{47}$ On further changes to the tower, see ZYKAN 1967 (see in note 19), pp. 106-109, 176-178; BÖKER 2007 (see in note 1), pp. 118-131. On the nave, see BÖKER 2007 (see in note 1), pp. 164-226; JUCKES, T.: Gewölbe der Stephanskirche. Wien als Architekturzentrum im Mitteleuropa des 15. Jahrhunderts. In: Wiener Jahrbuch für Kunstgeschichte, 62, 2014, pp. 39-62.
}

48 The basis for the generally accepted identification and common workshop origin of the figures was established by Antje Kosegarten; see KOSEGARTEN, A.: Plastik am Wiener Stephansdom unter Rudolf dem Stifter, PhD thesis. Freiburg 1960; Idem: Parlerische Bildwerke am Wiener Stephansdom aus der Zeit Rudolfs des Stifters. In: Zeitschrift des deutschen Vereins für Kunstwissenschaft, 20, 1966, pp. 47-78. See also: came to rest on the springing zone of the transept's southern vaults (fig. 8, no. 2). It comes as no surprise that such ad hoc devices are not found on the north tower, where the tower's scale and relations with neighbouring structures followed the system established at the start of works.

\section{Sculptural programming}

The plan changes suggest that a coordinated concept for nave and tower emerged relatively late and showed little sign of reverence for any long-standing Rudolfinian scheme. On the contrary, there is evidence of growing ambition and a willingness to embrace new ideas - a tendency that was sustained in subsequent phases of construction and led to further alterations in the concluding stages of work on the tower and nave. ${ }^{47}$ In my final section, I want to seek a broader understanding of this dynamic by consulting other visual media, namely the church's cycles of integral sculpture.

The first issue is the fate of products of the so-called ducal workshop (Herzogenwerkstatt) - a substantial body of material closely tied to the person and patronage of Rudolf IV. If this is difficult to assess in some cases, then distinctive patterns of reception are documented by at least one important example - the six Fürstenfiguren (c. 1359-65), a series of over-lifesize sandstone sculptures that can be identified as Rudolf and Katharina, together with their parents, Albrecht II and Johanna of Pfirt, and Karl/Karel IV and Blanche of Valois (fig. 9). ${ }^{48}$ While forming three contrapostal and mutually

TIETZE 1931 (see in note 27), pp. 521-528; GINHART, K.: Die Fürstenstatuen von St. Stephan in Wien und die Bildwerke aus Grosslobming. Klagenfurt 1972; SCHMIDT, G.: Die Wiener „Herzogswerkstatt“ und die Kunst Nordwesteuropas. In: Wiener Jahrbuch für Kunstgeschichte, 30-31, 1977-78, pp. 179206, republished in Idem: Gotische Bildwerke und ibre Meister. Vienna 1992, pp. 142-174; SCHWARZ, M. V.: Höfische Skulptur im 14. Jh. Entwicklungsphasen und Vermittlungswege im Vorfeld des Weichen Stils. Worms 1986, pp. 302-305, Idem: Magnifizenz und Innovation: Rudolf IV. im Bild. In: ROSENBERG SCHWARZ 2015 (see in note 12), pp. 34-41; SALIGER, A.: Bischofstor und Stifterfiguren. In: KASSAL-MIKULA 1997 (see in note 4), pp. 104-107; SCHULTES, L.: Die Plastik -Vom Michaelermeister bis zum Ende des Schönen Stils. In: BRUCHER 2000 (see in note 2), pp. 355-357; SAUTER, A.: Fürstliche Herrschaftsrepräsentation: Die Habsburger im 14. 


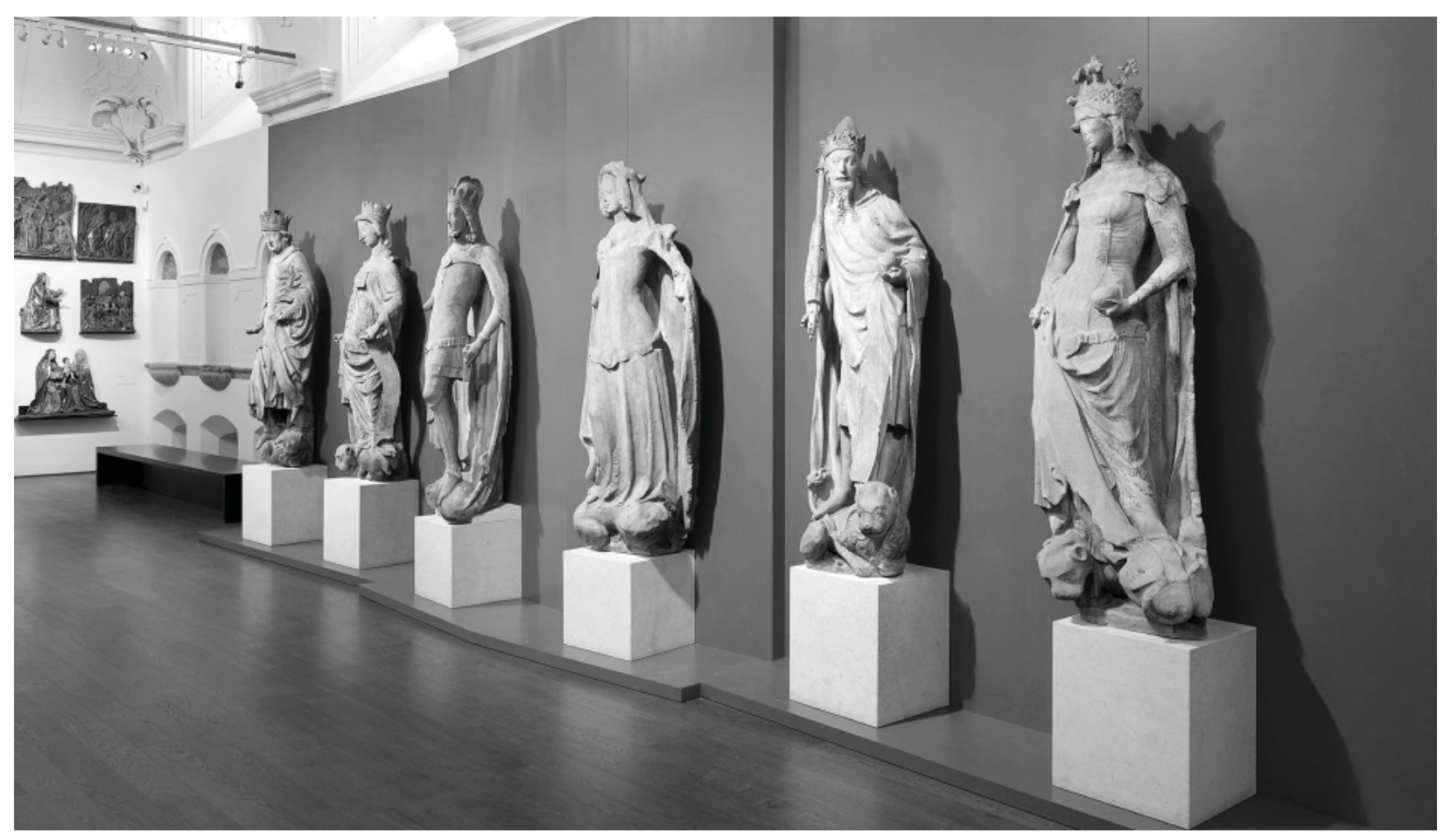

Fig. 9. Fürstenfiguren, c. 1360/5: current installation in Belvedere (Wien Museum). Photo: Vienna University, Unidam

inclined pairs, the statues are also clearly articulated as a group: they share a highly specific format and refined stylistic traits. ${ }^{49}$ That the works were intended for collective installation immediately seems likely and finds further confirmation in the dependant character of Karl IV and Blanche in a Viennese context: with the imperial couple lacking any direct connection to St. Stephen's, their presence only acquires meaning within the orbit of their daughter and son-in-law. The pivotal role of Rudolf and Kath-

Jahrhundert, Ostfildern 2003, pp. 223-225; BÖKER 2007 (see in note 1), pp. 61-70; PINKUS, A.: The Founder Figures at Vienna Cathedral. Between Imago and Symulachrum. In: Marburger Jahrbuch für Kunstwissenschaft, 40, 2013, pp. 63-92; WOLFINGER 2018 (see in note 3), pp. 83-84, 467-468.

${ }^{49}$ On the group character of the works and their apparent conception for a common installation: KOSEGARTEN 1960 (see in note 48), p. 50; SCHMIDT 1977-1978 (see in note 48), pp. 154-155; SCHWARZ 1986 (see in note 48), pp. 302-305.

${ }^{50}$ Such as the genealogy in the great hall at Karlstejn (mural paintings, c. 1355-1370s) and the series of busts installed in the lower triforium of Prague Cathedral (late 1370s); see arina, moreover, was emphasized by artistic means - particularly the use of cloaks as an expansive foil for the pair's dynamically stylized bodies, a spatially assertive motif that is absent from the parent figures. Such a visualization of kinship in monumental stone format was unusual for its time, but hardly seems out of place within the wide-ranging artistic strategies of Rudolf IV: on one level, it can be related to genealogical cycles emerging from other contemporary courts, including that of Karl IV; ${ }^{50}$

HOMOLKA, J.: The Pictorial Decoration of the Palace and Lesser Tower of Karlštejn Castle. In: Magister Theodoricus, Court Painter to Emperor Charles IV: The Pictorial Decoration of the Shrines at Karlstejn Castle. Ed.: FAJT, J. Prague 1998, pp. 50-59; BARTLOVÁ, M.: The Choir Triforium of Prague Cathedral Revisited: The Inscriptions and Beyond. In: Prague and Bohemia: Medieval Art, Architecture and Cultural Exchange in Central Europe. Ed.: OPAČIĆ, Z. Leeds 2009, pp. 81-100. Important points of reference for both the Viennese and Bohemian examples probably came from French courtly circles - see particularly the figural cycles of the Grand' Salle at the Palais de la Cité (by c. 1313) and the Louvre staircase of Charles V (1360s-70s); see SCHWARZ 1986 (see in note 48), pp. 88-93, 119-127. 
on a local level, a slightly abbreviated model from the early fourteenth century existed at nearby Tulln, where the Habsburg founder of the Dominican nunnery, Rudolf I, had ordered sculptures of himself, his son, and their wives - all of which were placed on piers around the family tomb before the church's high altar (by 1290). ${ }^{51}$ With its specific cast of portraitesque figures, refined surfaces, and acribic detailing, the Vienna cycle seems predestined for an environment of this kind - most likely in the vicinity of the ducal tomb in the choir of St. Stephen's or at an entrance connected to this space. ${ }^{52}$

If the original intention behind the Rudolfinian commission remains uncertain, then the subsequent scattering of the figures across the exterior of St. Stephen's is more easily reconstructed. Rudolf and Katharina were placed in niches on the corners of the west front around nine metres above ground-level, where they were complemented by pairs of secondary arms-bearing figures - certainly in the case of Katharina and presumably for Rudolf, although this is not documented (fig. 2/a-b, fig. 10). ${ }^{53}$ As part of the buttressing for the west chapels, these triplet-niches were probably available by the late fourteenth century, although work on the upper chapels was only completed several decades later (by c. 1430) $)^{54}$; it is thus conceivable that the statues

\footnotetext{
51 The group has not survived, but received illustrated entries in Marquard Herrgott's Monumenta. See HERRGOTT, M.: Monumenta Augustae Domus Austriacae. Tomus III: Pinacotheca Principum Austriae, vol. 1. Vienna 1760, figs. 14/1,16/3,17/1,17/4; Idem 1760/2, pp. 2, 14-15, 20; Idem: Monumenta Augustae Domus Austriacae. Tomus IV: Tapographia Principum Austriae, vol. 1. Vienna 1772, pp. 130-132; Idem 1772/2, fig. 9; SCHWARZ 1986 (see in note 48), pp. 282-285; Barbara Schedl in: BRUCHER 2000 (see in note 2), pp. 227-228.
}

52 The argument for the choir is strengthened by the presence there of a related statue of Rudolf's brother, Duke Friedrich, who died in 1362 and was laid to rest in the new crypt at St. Stephen's; the figure received an illustrated entry in Marquard Herrgott's Monumenta (1760/1, fig. 25/4), but has since been lost. The Fürstenfiguren could have served in a similar manner - as prominent visualizations of those commemorated in the choir: while Rudolf's parents were buried elsewhere, the duke made provisions for their souls at St. Stephen's and his cenotaph refers to them explicitly in its inscription; the addition of Karl IV and Blanche may partly reflect Katharina's wishes, partly Rudolf's desire to emphasize his imperial connections - a recurring motif of arrived here towards the end of building work on this section of the church and were immediately provided with arms-bearers, which stylistic analysis has dated to c. 1420/30 at the earliest. ${ }^{55}$ The parent figures, meanwhile, were housed in niches across the double-window stage of the south tower, which had been completed by 1407 (fig. 2/c-f). ${ }^{56}$ These installations involved not only separating the central pair from their accompanying parents, but also splitting the pairs themselves: the physical distance between Rudolf and Katharina - around $40 \mathrm{~m}$ - meant that their duality, which had been carefully articulated by the artist(s), was obscured; the placement of Katharina to Rudolf's right - in an apparent reversal of the original conception exacerbated the problem. On the south tower, the same issues were compounded by the architectural complexity of the corner buttressing, the greater height of the figures' installation (at around $15 \mathrm{~m}$ ), and their cramped niches: the armorial devices and fine detailing are rendered meaningless; even with allowance for a polychrome finish, the figures fade into non-descript rulers when viewed from ground level. ${ }^{57}$ While they soon sunk into obscurity and were only re-identified following their musealization, the more accessible statues on the west front featured in early descriptions of the church and received

his self-presentation; see WOLFINGER 2018 (see in note 3), pp. 467-471.

${ }^{53}$ Herrgott documents only the arms-bearers accompanying Katharina - as had Testarello before him (1685): HERRGOT'T 1760/1 (see in note 51), fig. 24; Wiener Dombauvereins-Blatt, Series 2. Ed.: NEUMANN, W. A. 1889-99, p. 188.

${ }^{54}$ SCHEDL 2018 (see in note 2), pp. 117-118.

55 See SALIGER 1997 (see in note 48), pp. 128-129 (with dating to soon after 1420); BÖKER 2007 (see in note 1), p. 70 (mid-fifteenth century); see also KOSEGARTEN, A.: Parlerische Bildwerke am Wiener Stephansdom aus der Zeit Rudolfs des Stifters. In: Zeitschrift des deutschen Vereins für Kunstwissenschaft, 20, 1966, p. 56.

56 See above, p. 117.

57 The south-tower niches offer an unimpaired opening with a height of only c. $195 \mathrm{~cm}$ (measured from the surface of the plinth to the hanging lily of the tracery crown) for statues that are c. $220 \mathrm{~cm}$ tall. 


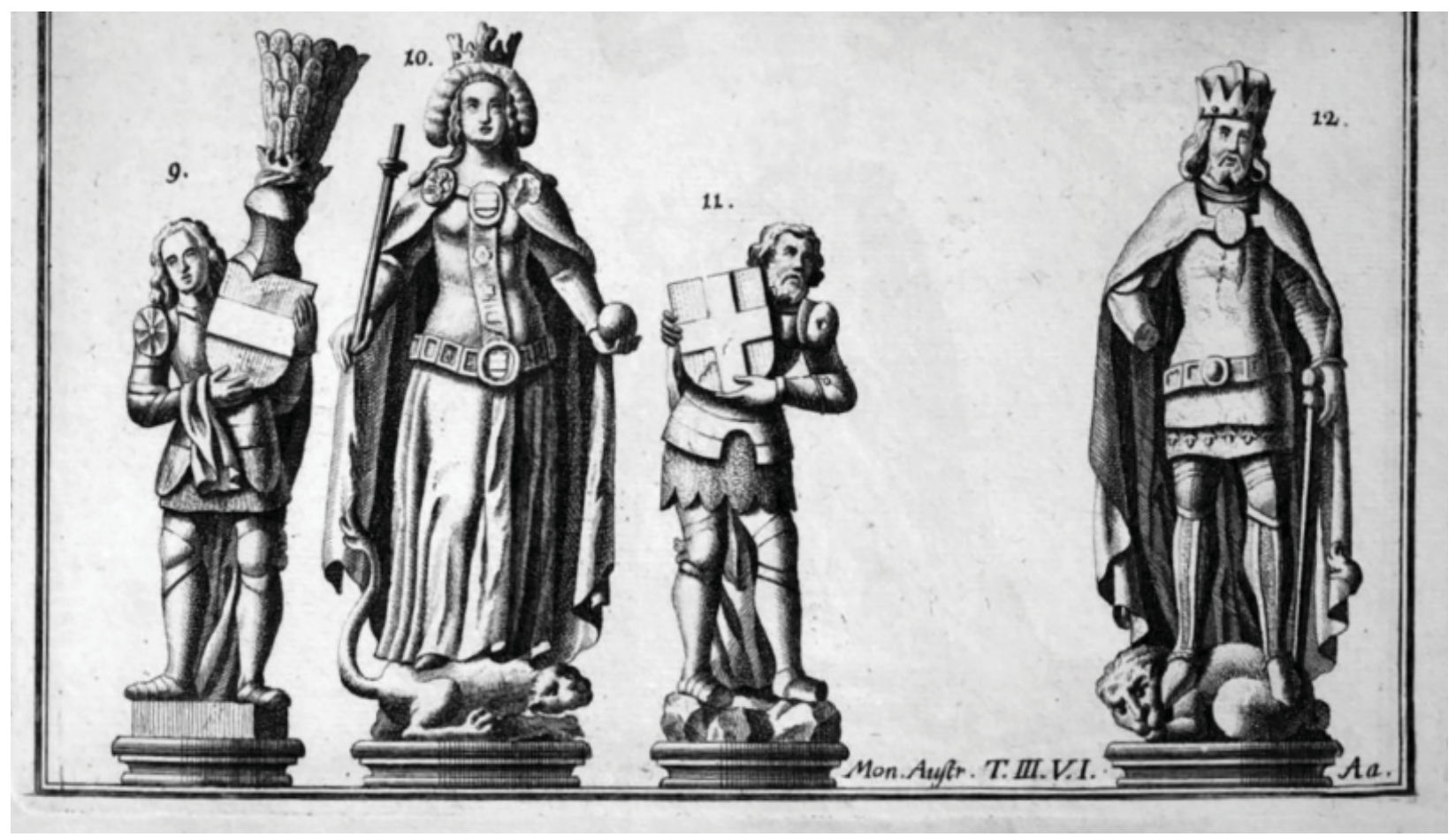

Fig. 10. Fürstenfiguren, c. 1360/5: figures of Katharina with arms-bearers and Rudolf, engraving from Marquard Herrgott's Pinacotheca. Repro: HERRGOTT 1760 (see in note 51)

illustrated entries in Marquard Herrgott's Monumenta (1750-72; fig. 10). ${ }^{58}$

The new installation of the statues saw not only the fragmentation of a carefully conceived cycle, but also a degree of reprogramming. In supporting the legibility of the figures for viewers below, the shields presented by Katharina's secondary companions were no simple amplification of the small-scale arms on her clothing, which - with the double-tailed lion accompanying the striped Austrian shield on the shoulder clasps of her cloak - referred clearly to her Bohemian origins: the two assistants instead presented the arms of Austria and Vienna, introducing a civic perspective that is otherwise absent

\footnotetext{
${ }^{58}$ For Testarello's description of 1685: NEUMANN 1889-1899 (see in note 53), p. 188. See also HERRGOT'T 1760/1 (see in note 51), fig. 24; OGESSER, J.: Beschreibung der Metropolitankirche zu St. Stephan in Wien. Vienna 1779, pp. 71-72.

59 The armorial devices on Katharina's clasps, which were documented by Herrgott, remain only faintly visible today;
}

from the cycle, where - as in other instances of Rudolf's patronage - the city did not receive separate representation (fig. 10). ${ }^{59} \mathrm{~W}$ ith the adjustments on the west façade, the church's civic component finds expression, while the figures of Rudolf and Katharina lose profile and were sooner or later reduced to the role of unspecified ducal protectors: even if their contemporary reception is not documented, early modern sources show a lively range of identifications ranging from Albrecht II to Albrecht V; the more reasoned view of Marquard Herrgott - who had taken the trouble of examining the figures and their armorial devices at close quarters - failed to gain traction. ${ }^{60}$

see HERRGOT'T 1760/1 (see in note 51), fig. 24; 1760/2, 80.

${ }^{60}$ See Testarello in NEUMANN 1889-1899 (see in note 53), p. 188; HERRGOTT 1760/1 (see in note 51), fig. 24; id. 1760/2, 80; OGESSER 1779 (see in note 58), pp. 71-72; TIETZE 1931 (see in note 27), pp. 525-526. 
The visual culture of the burghers becomes still more tangible in sculptural cycles commissioned after Rudolf's death, the most important of which are the pier figures of the nave. Arranged in stacked groups within the support system of the main arcades and side walls, the numerous niches and their elaborate baldachins are a striking feature of the design as it had emerged by the late fourteenth century, although the 77 figures were only executed as work on the lay church neared completion in the mid-fifteenth century. ${ }^{61}$ Attempts to fit the cycle into the mould of princely patronage - as the remnants of a grand programme relating either to Rudolf IV's original plans or to the preferences of Friedrich III - face an array of problems. ${ }^{62}$ Firstly, there is the documented role of the burghers in commissioning the figures: fourteen of the statues still have coats of arms or donor figures, which - in the cases that can be identified - all come from a patrician milieu; nothing refers to princely patronage. ${ }^{63}$ Secondly, there are the instances of repetition within the cycle - three Virgins (with Child), two Virgins of Mercy, two Virgins Annunciate with accompanying figures, three figures of John the Baptist and Sebastian, two Christophers

\footnotetext{
${ }^{61}$ With the exception of a few figures, the cycle - which finds no mention in written sources - has been dated by stylistic analysis to c. 1440 to 1475 ; the wide range of datings reflects the difficulties of the evidence and its dependence on a building history that itself has been subject to revision. See: TIETZE 1931 (see in note 27), pp. 394-417; ZYKAN 1981 (see in note 7), pp. 109-116; Idem: Zu Entstehung und Programm der gotischen Figurenzyklen in St. Stephan in Wien. In: Österreichische Zeitschrift für Kunst und Denkmalpflege, 54, 2000, pp. 347-358; ELSIGAN, M.: Die Pfeilerplastiken im Langhaus von St. Stephan zu Wien: Hintergründe - Stil - zeitliche Stellung, Diploma thesis. Vienna 1989, pp. 52-89; BÖKER 2007 (see in note 1), pp. 239-245; HAUSNER, F.: Die Pfeilerfiguren im Langhaus von St. Stephan in Wien. Aufstellungskonzept und Funktion, MA thesis. Vienna 2012, pp. 8-14, 45-50 (with further literature).
}

${ }^{62}$ See ZYKAN 2000 (see in note 61), pp. 347-358; BÖKER 2007 (see in note 1), pp. 239-245. Felicitas Hausner has recently shifted the discussion towards the cycle's role in the church's liturgy, but - in seeking to reconstruct a grand design from this perspective - faces the same problems as those addressing the cycle as an object of princely patronage; see HAUSNER 2012 (see in note 61).

${ }^{63}$ On the identifiable armorial devices, see PERGER, R.: Zur Datierung einiger Bildwerke im Langhaus des Wiener Stephansdomes. In: Österreichische Zeitschrift für Kunst und Denk- and Stephens, and so on. ${ }^{64}$ Involving around a third of the cycle's figures, this phenomenon can hardly result from occasional lapses in planning: it implies far more that a programmatic reading of the cycle as a whole was never intended. The apparent confusion, thirdly, cannot be blamed on later rearrangements, which - except in a few exceptional cases ${ }^{65}$ - are neither documented nor seem plausible: with their lifesize format and execution in stone, these are heavy and fragile objects that, in many cases, could only be fitted into their niches by cutting back the baldachin structure. ${ }^{6}$ Any alterations, moreover, would have required a swap, since all but one of the niches in the nave and crossing were occupied. Why so much effort only to create chaos?

Examined as a series of choices made by individual patrons or groups, however, the current installation appears less arbitrary. On a general level, as Felicitas Hausner has recently shown, there was a marked preference for locally venerated saints, particularly those whose relics were present at the church. ${ }^{67}$ The cycle's recurring saints, moreover, were particularly well represented within the church's relic collection. ${ }^{68}$ On a more specific level, many figures show

malpflege, 42, 1988, pp. 109-113. Further marks of patronage on or around the figures have probably been lost over the centuries.

${ }^{64}$ Listed here are only the clear cases of repetition. In the case of four further recurrences - John the Evangelist, Andrew, Matthew, and Catherine (each represented in the cycle two times) - post-medieval attributes make the original identity questionable; see HAUSNER 2012 (see in note 61), pp. 4344, 157-163.

${ }^{65}$ Ibidem, pp. 50-51.

${ }^{66}$ For an extreme case of cutting, see the Crucifixion at the centre of the south-aisle wall (fig. 13).

${ }^{67}$ HAUSNER 2012 (see in note 61), pp. 51-52, 86-98, 164; see also ZYKAN 2000 (see in note 61), p. 355.

${ }^{68}$ The church's late medieval relic collection is documented by the so-called Heiligthumbuch of 1502, which mentions the following reliquaries pertaining to saints that recur within the nave cycle (excluding further relics that were presented alongside those of other saints in composite reliquaries): seven reliquaries for Stephen, six for Andrew, four for John the Baptist, four for Catherine, three for Sebastian, two for Christopher, one for John the Evangelist. It also devotes a 


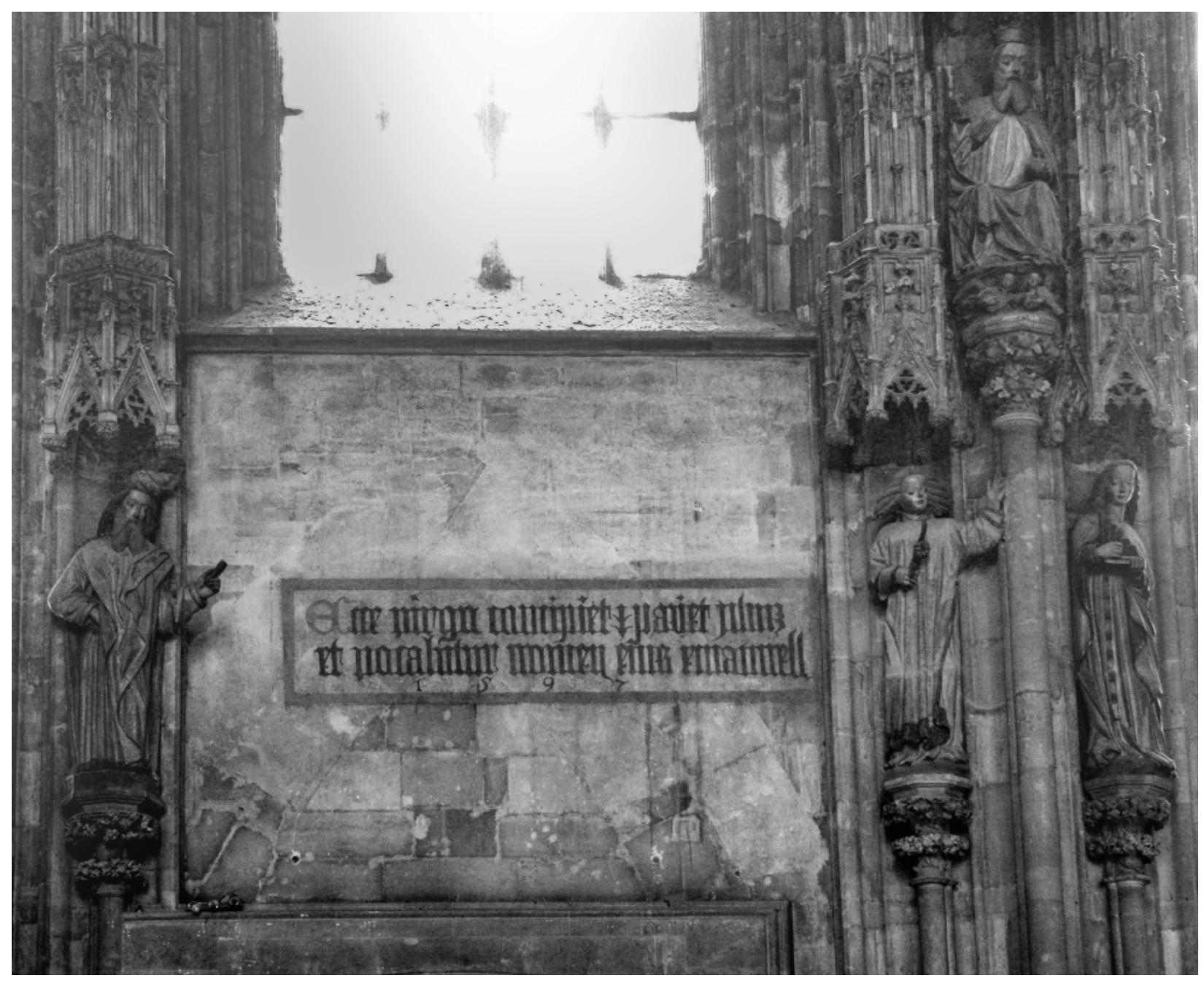

Fig. 11. Nave, pier figures, mid-fifteenth century: Annunciation group above north-west portal. Photo: T. Juckes

responses to aspects of the church's topography. Particularly well preserved is the role of portals in the western nave, where the presence of the main ceremonial portal beneath the west gallery (Riesentor) and two important side-portals (Bischofstor, Singertor) created an entrance zone that had an extensive impact on nearby pier figures (fig. 2). When framing

whole section, containing 30 reliquaries, to the Virgin. See Das Wiener Heiligthumbuch nach der Ausgabe vom Jahre 1502 samt den Nachträgen von 1514. Ed.: K.K. Österreichisches Museum für Kunst und Industrie. Vienna 1882; HAUSNER 2012 (see in note 61), p. 164 (with table of relics pertaining to saints from the nave cycle). the entrances themselves, a favoured choice was a scene closely associated with sacred thresholds in late medieval thought - the Annunciation: as the moment of Christ's incarnation and the Virgin's manifestation as gate to heaven, this scene was often deployed at portals, but also across choir thresholds or on the closed wings of altarpieces. ${ }^{69}$ The two Annunciations

${ }^{69}$ The deployment of Annunciations across Viennese portals can be traced back at least to the mid-fourteenth-century pair that flanks the central west entrance to the church of the Friars Minor. On the long tradition of Annunciation scenes across choir arches and the connections to sacred theatre: TRIPPS, J.: Das handelnde Bildwerk in der Gotik. Berlin 2000, pp. 
in question here - found at the north-west portal and on the central arch of the west gallery - make emphatic use of their liminal settings, both playing out across the entrances concerned (fig. $2 / \mathrm{g}$, i). As the church's main Marian portal, the north-west entrance particularly invited this iconographical choice: it shows Isaiah on its west side, whose prophesy Ecce virgo concipiet... runs in monumental script across the top of the portal to join with the stepped trio of God the Father, the angel Gabriel, and the Virgin (fig. 2/g, fig. 11). On the west gallery, the Annunciation shows a two-tier arrangement on either side of the broad central opening before the west portal: a pair of prophets occupy the lower storey with Gabriel and the Virgin above, both groups clearly communicating across the intervening space (fig. $2 / \mathrm{i}$ ).

As the presence of yet another, earlier Annunciation (c. 1360) on the external jambs of the same north-west portal shows, repetition was simply not a concern here (fig. 2/h). A similar phenomenon, moreover, occurs at the south-west portal, where the external jamb figures of Moses and Christ the Saviour (c. 1360) - as emblems of the Old and New Testament - find a subtle recasting inside the church (fig. $2 /$ j). Immediately opposite the entering visitor,

88-94. For an interesting fusion of two traditions - Annunciations on choir arches and retables - see the Church of Our Lord in Creglingen, where two retables with Annunciations on the closed wings were placed on side-altars flanking the triumphal arch in the late fifteenth century; see JUCKES, T.: The Creglingen Altar and its Multimedia Environment: Metamorphoses of a Furnishing Ensemble in Sacred Space ca. 1460-1510. In: Riemenschneider in situ. Eds.: BOIVIN, K. BRYDA, G. Turnhout 2020 / forthcoming.

${ }^{70}$ The legend that she visited Sinai and built a tower at the site of the Burning Bush - which was later to be incorporated within the monastery of St. Catherine - goes back to the tenth century (first mentioned by Eutychius of Alexandria in his Annals). While this tradition is not mentioned by Felix Fabri - the Ulm Dominican and preacher who wrote a detailed account of his pilgrimage to the Holy Land in 1483 - he does report that the main choir altar of the monastery church was dedicated to Sts. Helena and Constantine. Visitors in subsequent centuries documented further embellishments to her alleged role in the early history of the site - Helena as founder of the Chapel of the Burning Bush, builder of 1400 steps leading up the mountain, etc. See Fratris Felicis Fabri evagatorium in Terrae Sanctae, Arabiae et Egypti peregrinatione, vol. 2. Ed.: HASSLER, K. Stuttgart 1843, p. 498; BRAUN, J.: St. the two nearest pier figures of the nave arcade form a pair that inclines diagonally towards the portal: to the north-east Moses recurs with an even larger and now legibly inscribed tablet; to the north-west, St. Helena can be seen with the True Cross (fig. 2/k, fig. 12). Their joint appearance here may relate to Helena's fourth-century activities in the Holy Land, which by the late Middle Ages were thought to have extended to the Sinai sites most closely associated with Moses $;{ }^{70}$ the True Cross - which she also discovered during her stay, an event marked in the fifteenth century by its own feast-day (3 May) and procession - in any case forms a pendant to the tablet and reiterates the portal's external reference to the Old and New Testaments. ${ }^{71}$

Alongside such instances of liminal sensitivity, another important factor in the choice of pier figures was the dedication of altars. ${ }^{72}$ This helps to explain some of the remaining figures in the western nave: the altar of St. Martin in the south-west corner was flanked by two bishops that cannot be identified with certainty, but seem fitting company for Martin as a prominent bishop saint (fig. $2 / 1) .{ }^{73}$ The analogous niches flanking the altar of St. Andrew in the north-west corner were partly occupied by the aforementioned Annunciation, partly by a figure of

Catherine's Monastery Church, Mount Sinai: Literary Sources from the Fourth through the Nineteenth Centuries, PhD thesis. Michigan 1973, pp. 4-5, 79, 176, 179, 251; CANER, D.: History and Hagiography from the Late Antique Sinai. Liverpool 2010, pp. $17,277$.

71 The argument for Helena's inclusion in the nave cycle may have been strengthened by the presence of her relics at the church (most notably an arm relic; see the Heiligthumbuch of 1502, section 8, no. 18); she was also co-patron of the large crypt beneath the charnel chapel opposite the south-west nave portal. For a similarly oriented figure of Helena near a portal in St. Sebald's in Nuremberg and its connections to processions held on 3 May, see WEILANDT, G.: Die Sebalduskirche in Nürnberg: Bild und Gesellschaft im Zeitalter der Gotik. und Renaissance. Petersberg 2007, pp. 275-276.

${ }^{72}$ For a different view of the role of altars in the choice of pier figures, see HAUSNER 2012 (see in note 61), pp. 52-114; this assumes - in contrast to the arguments developed here substantial disruptions to a carefully conceived programme in later periods. See also ZYKAN 2000 (see in note 61), p. 355.

${ }^{73}$ HAUSNER 2012 (see in note 61), nos. 59-60; on the Martin altar: SCHEDL 2018 (see in note 2), pp. 57, 72, 113. 

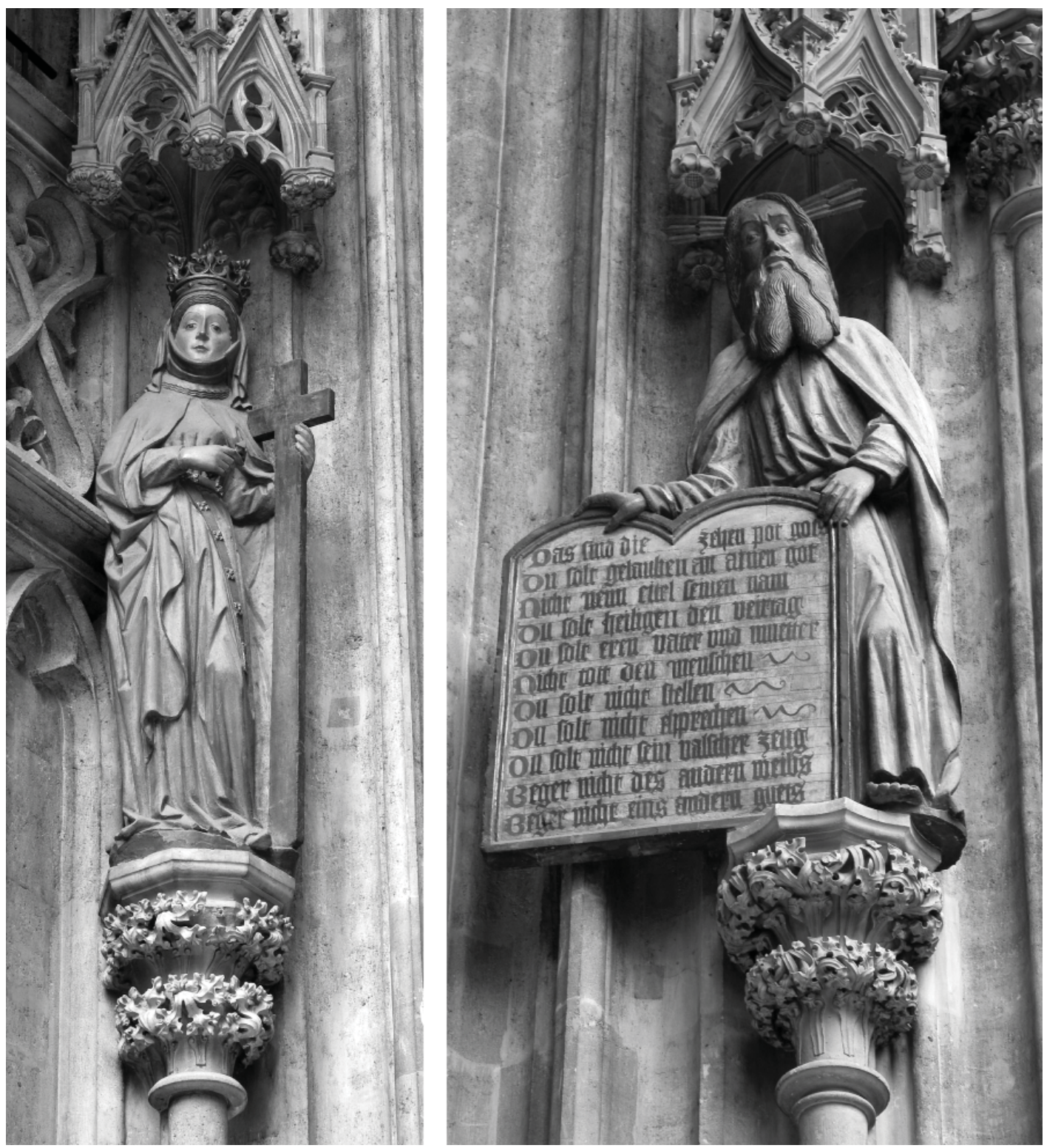

Fig. 12. Nave, pier figures, mid-fifteenth century: Helena and Moses opposite the south-west portal. Photo: T. Juckes

St. Anthony the Great that cannot immediately be explained; nonetheless, the adjacent niche on the western gallery does house a figure of St. Andrew, which can only refer to the saint's nearby altar (fig.

\footnotetext{
${ }^{74}$ Such an additional reference to St. Andrew makes particular sense given the status of both the saint and his altar here: the church held an impressive collection of his relics and, as mentioned in the preamble of the Heiligtbumbuch of
}

$2 / \mathrm{m}) \cdot{ }^{74}$ Moving further east, the altar of St. Catherine on the northern arcade elicited a slightly different response in the three niches on the pier's north side: here the Virgin was placed in the raised central niche

1502, substantial indulgences (320 days) were permanently available at his altar. See above, n. 68; HAUSNER 2012 (see in note 61), p. 62; SCHEDL 2018 (see in note 2), pp. 111, $120-121$. 
with Catherine and another female martyr flanking her below. In its stepped format, in the subordination of Catherine as altar patron to the Virgin, and in the addition of an appropriate companion saint (possibly a co-patron) to complete the trio, the arrangement responds to the altar's dedication in a manner reminiscent of contemporary retables (fig. $2 / \mathrm{n}$ ). ${ }^{75}$ Similar in function but showing further variation in disposition is the four-figure Epiphany group that encircles the southern crossing pier and most likely relates to a nearby altar of the Three Kings (fig. $2 / 0$ ). ${ }^{76}$ More source information on the locations, patrons, and co-patrons of altars would probably reveal further connections to adjacent pier figures. ${ }^{77}$

Important altars in the lay church were concentrated not only along the choir threshold, but also across the north-south axis at the centre of the nave. As Barbara Schedl has shown, the two altars that had been placed on the corresponding arcade piers here by around 1420 - dedicated to All Souls (north pier) and All Saints (south pier) - played an important role in parish liturgy and were accompanied by other key furnishings, including the stone pulpit and baptismal font (fig. $2 /$ p-q) ${ }^{78}$ By the early sixteenth century, the All Souls" altar "at the font" (as it was described) had become the starting point for Corpus Christi processions and was equipped with its own sacrament house. ${ }^{79}$ While in this case the figures of

${ }^{75}$ On the altar's position, see SCHEDL 2018 (see in note 2), pp. 56-57, 99.

${ }^{76}$ The altar seems to have stood before the choir screen, but its exact position is not certain and changed at least once. First mentioned in 1348, its transfer is documented in 1443 as ongoing, but without reference to its former or future location; by 1454, it was back in use. Several decades later and together with the Wolfgang altar, it received a new anniversary mass and was referred to as standing at the entrance to the choir next to the screen (Acta capitulorum, 1473): in altari trium regum et sancti Wolfgangi contiguo cancelleum, ubi intratur ad chorum. See HAUSNER 2012 (see in note 61), pp. 27, 31; SCHEDL 2018 (see in note 2), pp. 124-125, 133-4; GÖHLER, H.: Das Wiener Kollegiat-, nachmals Domkapitel zum hl. Stephan in seiner persönlichen Zusammensetzung in den ersten zwei Jahrhunderten seines Bestandes 1365-1554, PhD thesis. Vienna 1932 / published Vienna 2015, p. 308.

77 Some further clues come from post-medieval altar furnishings that often refer back to earlier patrons and co-patrons. See, for instance, the figure of St. Sebastian crowning the altarpiece the arcade piers show no obvious reaction to altar dedications, the scenic groupings on the piers of the side walls do seem to respond to this pivotal zone mitten in bemelter Kirchen ("in the middle of the said church"). ${ }^{80}$ Just as it was deemed appropriate to flank portals with Annunciations, so figural scenes with two cornerstones of salvific history were selected here to mark the centre of the space: on the south side, a stepped grouping with the Imprisonment and Way to Calvary crowned by a central Crucifixion (fig. 2/r, fig. 13); on the north side, the Resurrected Christ, accompanied by Mary Magdalene and another female saint (fig. 2/s). Particularly on the south side, where the Passion cycle extends to the neighbouring piers with a Mount of Olives (to the west) and Lamentation (east), the elaborate scenic conceptions push the pier-figure genre to its limits. Even if the Passion cycle was not extended further along the south wall, the sense of a thematic and medial accentuation of the lay church's central zone remains.

Portals and altars were probably not the sole basis for patronal decisions. The limits of the evidence, however, means that other potential factors - particularly the role of nearby tombs and the personal preferences of individuals and families - can only be inferred from the more comprehensively preserved ensembles of other churches. ${ }^{81}$ Nonetheless, the intrinsic logic of the cycle as a product of civic

of Sts. Peter and Paul (1677) or the similarly placed St. John the Baptist on the altarpiece of the Virgin in the Sun (1699) - both figures that recur in immediately adjacent pier niches (Tietze nos. 22 and 58). See NEUMANN 1889-1899 (see in note 53), pp. 186-187, 193-194; TIETZE 1931 (see in note 27), pp. 281-287, 296-297; ZYKAN 1981 (see in note 7), p. 169.

${ }^{78}$ SCHEDL 2018 (see in note 2), pp. 112-116, 156-157.

79 See the book of the Corpus Christi Fraternity (Diözesanarchiv Wien), where - in reference to events of 1508 - the altar was described in these terms: auf aller Seelenaltar bey dem Taufstein mitten in bemelter Kirchen; see SCHEDL 2018 (see in note 2), pp. 156-157.

${ }^{80}$ See above, n. 79. Similarly, in a 1430 reference to university ceremonies, seating was to be set up "in the middle of the church around the altar of All Souls" (in medio ecclesia circa altare animarum); see SCHEDL 2018 (see in note 2), p. 114.

${ }^{81}$ See, for instance, the extensive impact of family tombs and commemorative zones on various forms of imagery - 


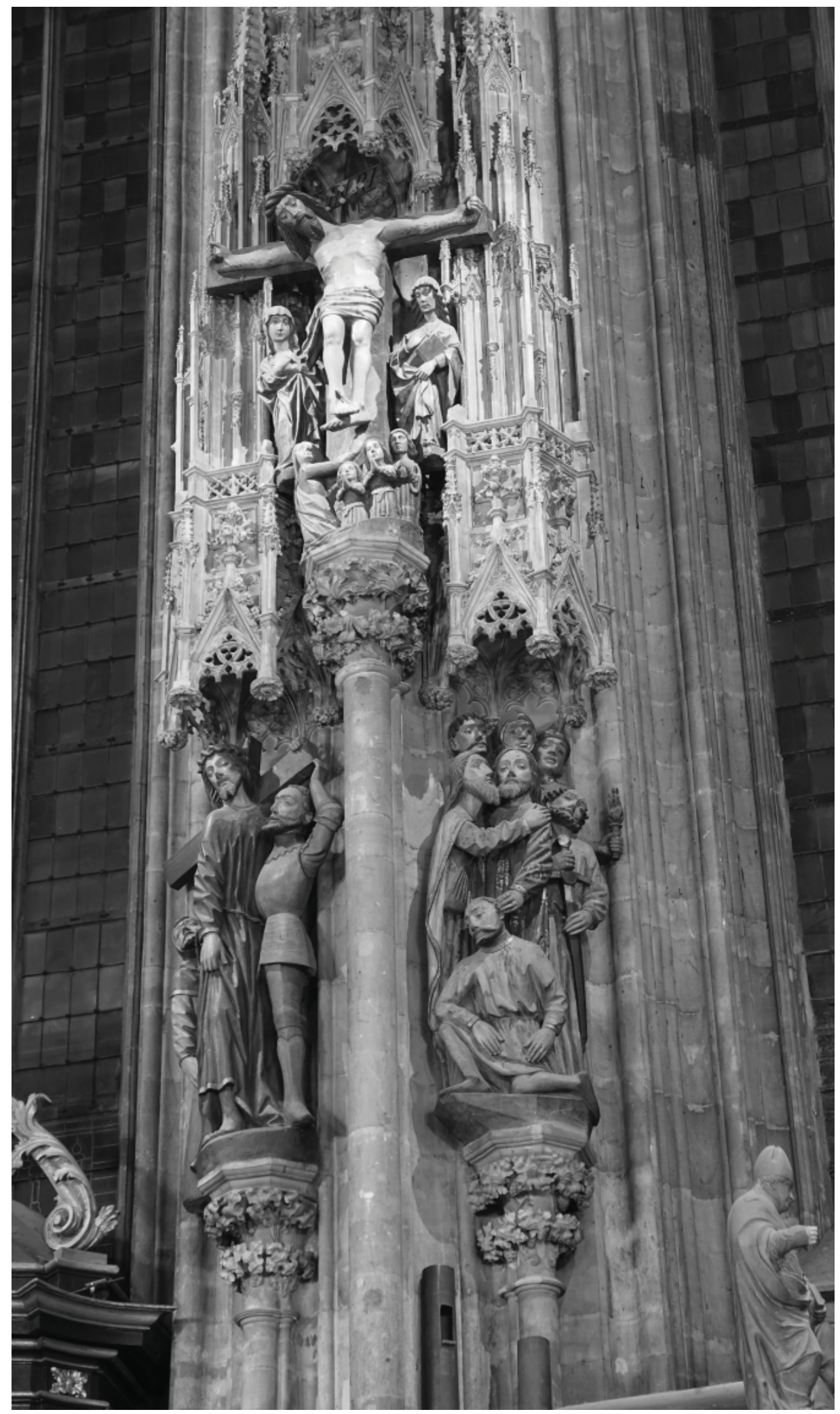

Fig. 13. Nave, pier figures, midfifteenth century: Passion group in the south aisle. Photo: F. Zehetner 
culture seems clear. The mass deployment of stone pier figures can be seen to continue a local tradition going back to the fourteenth century, but also as something more specific - as an amplification of the form to serve the city's main parish church and the commemorative needs of its congregation. ${ }^{82}$ In a complex that lacked extensive side-chapels or other partitioned areas for private memoria, the unusually numerous pier figures served as a supplementary medium that allowed prominent families a long-term presence in the space. As such, they are reminiscent of cycles of stained glass preserved in other urban churches - where the rights to glaze windows were sometimes shared out among prominent families with a keen sense of social hierarchy but limited stipulations on content: beyond adherence to a shared code of topographical decorum, this was essentially left to personal preference. ${ }^{83}$ The configuration of the Vienna cycle implies a similar process of distribution, whereby individual donors took on individual figures or groupings according to status and means. Even if the identity of many patrons remains unknown, the preserved coats of arms all relate to families with an established place in local networks of power. ${ }^{84}$

$$
* * *
$$

While far from comprehensive in scope, the material considered here does suffice to show wide-ranging departures from any ducal plans laid down in the late 1350 s or soon after. In the case of the south tower, the plan changes were clearly more than modest updates to an original scheme: the evidence indicates instead that the definitive plan for the structure and its integration with the body of the church only emerged in a series of later campaigns.

including pier figures - in the side-aisles of the choir at St. Sebald's in Nuremberg: WEILANDT 2007 (see in note 71), pp. 318-340.

${ }^{82}$ The tradition of richly articulated pier niches for monumental statuary in Vienna goes back to the choir of St. Stephen's (consecrated 1340), which offered spaces for up to 40 figures. An increasingly dense incorporation of such niches subsequently became a common feature of ambitious projects in the city (except in mendicant contexts), such as: St. Stephen's, lower west chapels (by c. 1366) and Catherine
In the case of integral sculpture, the same campaigns saw some of Rudolf's most important commissions installed in unforeseen contexts, while the new cycle for the nave piers had still less to do with his original intentions. The decisive role of the burghers in all these developments underlines the significance of a specific and shifting patronal constellation. It suggests, firstly, that Rudolf's impact should be measured not purely in terms of a putative masterplan, but rather seen as a process that worked through various channels. His foundations also proved to be a turning-point on a less direct level: by enhancing the institutional prestige and - particularly through an expanded relic collection - salvific power of the church, they at once heightened the attraction of St. Stephen's to urban society and put further pressure on an increasingly cramped site; by initiating lavish architectural and sculptural projects, the duke set new standards and enhanced Vienna's potential as an artistic centre. If this created propitious circumstances for burgherly interventions at St. Stephen's, then the rising structure of the lay church - and this is the second point - nonetheless merits attention as a project in its own right. It shows, on the one hand, a sustained aspiration to liturgical self-sufficiency with its elaborate altar landscape and independent facilities (sacrament house, music galleries, spacious sacristy, etc.); and, on the other, a quality of design that, in both dimensions and detailing, willingly surpassed adjoining structures and competed with other patrician ventures across Central Europe. In all these ways, St. Stephen's emerges as an idiosyncratic product of dual patronage - the unfolding achievement of court and city: it was neither one group nor the other, but rather the interactions of the two that came to define the late medieval site.

chapel (by 1396); Maria am Gestade, choir (by c. 1350) and nave (by 1414); chapel of the Teutonic order (by 1395); Hofburg chapel (by 1425). Multiple niches on single piers are first found in the lower west chapels at St. Stephen's, the nave of Maria am Gestade, and the Hofburg chapel.

${ }^{83}$ See, for instance, the careful sharing of glazing rights for windows in the new choir of St. Sebald's in Nuremberg (consecrated 1379): WEILANDT 2007 (see in note 71), pp. 120-132.

${ }^{84}$ PERGER 1988 (see in note 63), pp. 109-112. 


\section{A Tale of Two Churches \\ Court and Parish Projects at St. Stephen's in Vienna}

Résumé

Late medieval St. Stephen's has often been viewed through the lens of Habsburg patronage and remains closely associated with a series of rulers, whose names have become synonymous with parts of the structure ("Albertinian" choir, "Rudolfinian" nave, etc.). The present article shifts the focus from the court to the role of the urban parish during the fourteenth- and fifteenth-century rebuilding of the church. Expanding on documentary evidence for an interruption to works after Rudolf IV's early death in 1365, it shows that substantial parts of the new complex were constructed under the auspices of the burghers during later campaigns - with little input from the Habsburgs, and with little reverence for any long-standing Rudolfinian plans. These architectural findings are then related to the church's cycles of integral sculpture from the same period, which show similar phenomena: on the one hand, important $\mathrm{Ru}-$ dolfinian works (such as the Fürstenfiguren, c. 1359-65) were later placed in unforeseen contexts following interventions by the burghers; on the other, new commissions (such as the numerous pier figures of the nave, mid-fifteenth century) were the product of patrician patronage and had still less to do with Rudolf's original intentions. In this way, St. Stephen's is explored as a finely calibrated ensemble of visual media that arose from an idiosyncratic form of dual patronage: it was ultimately neither court nor city, but rather the interactions of the two groups that came to define the late medieval site. 